\title{
14. MESSINIAN PALEOENVIRONMENTS: NEW EVIDENCE FROM THE TYRRHENIAN SEA (ODP LEG 107) ${ }^{1}$
}

\author{
Maria Bianca Cita, ${ }^{2}$ Sergio Santambrogio, ${ }^{2}$ Beatrice Melillo, ${ }^{2}$ and Francesca Rogate ${ }^{2}$
}

\begin{abstract}
The data base for this study is represented by essentially nonevaporitic Messinian sediments recovered at ODP Sites $654,653,652$, and 656 along the eastern Sardinian margin, and of the overlying early Pliocene oozes. Grain-size distribution, carbonate content, and microscopic observation of the sand size fractions were investigated.

Messinian paleoenvironments, documented in the western Tyrrhenian Sea (ODP Sites 654 and 653), provide additional evidence supporting the deep basin desiccation model. A sharp lithologic contrast between early Pliocene pelagic oozes and latest Messinian conformable gypsiferous silts supports this model. The "lago-mare" biofacies was only occasionally observed in the shallowest site and is limited to the topmost part of the Messinian.

Sites 652 and 656, lying in the deeper part of the Tyrrhenian and located on the downthrown side of an important eastward dipping fault system known as "Faglia centrale" are characterized by terrigenous sedimentation, with partly recycled minor evaporites. Of special interest is Site 652, where the thickness of the (probable) Messinian is $530 \mathrm{~m}$. Sedimentary characters indicate a permanently subaqueous but nonmarine environment, with turbidites accumulating in a rapidly subsiding basin.

According to the model proposed, this basin was fed by continental waters during times of maximum evaporitic draw-down, with temporary marine incursions from the west or southwest when the water level was higher. A basement ridge separated the evaporating pond from this endoreic lake located on the opposite (eastern) margin of the Tyrrhenian Basin, which was then limited to its western part. Post-Messinian reactivation of the "Faglia centrale" is necessary to account for the inversion of the relief.
\end{abstract}

\section{INTRODUCTION}

\section{Messinian Paleoenvironments}

Messinian sediments recovered from the sub-bottom of the Mediterranean during DSDP Legs 13 and $42 \mathrm{~A}$ record the history of an important salinity crisis (Ryan, Hsü, et al., 1973; Hsü, Montadert, et al., 1978).

These sediments consist essentially of evaporites indicative of subtidal, intertidal, and supratidal environments (Hsü et al., 1973; Garrison et al., 1978). Terrigenous sediments are interbedded with the evaporites, and overlie them in the eastern Mediterranean (DSDP Sites 374, 376). These terrigenous sediments may reach a few dozen meters in thickness.

Evaporites are barren or contain algal filaments indicative of the photic zone, but the associated terrigenous sediments may contain microfossils in some abundance such as diatoms (Hajos, 1973; Schrader and Gersonde, 1978), pollen (Bertolani Marchetti and Cita, 1975), foraminifers (Cita, 1973; Cita et al., 1978), and ostracods (Benson, 1973), indicative of a variety of environments, some of them mutually exclusive. Reworking of marine fossils originating from pre-salinity crisis sediments exposed on basin margins during evaporitic drawdown, and/or related to temporary marine incursions in nonmarine environments such as endoreic lakes were inferred (Hsü et al., 1973; Cita et al., 1978).

The terminal part of the Messinian is characterized both on land (Ruggieri, 1967) and in the deep-sea record of the eastern Mediterranean (Benson, 1973; Cita et al., 1978) by a brackish, shallow water fauna of ostracodes (Cyprideis pannonica agrigentina) and foraminifers (Ammonia beccarii tepida) which may contain mollusks and ostracodes endemic of the Paratethys. This biofacies is known as "lago-mare" and is widespread in the eastern Mediterranean borderlands (Sissingh, 1976) but has been

\footnotetext{
${ }^{1}$ Kastens, K. A., Mascle, J., et al., 1990. Proc. ODP. Sci. Results, 107: College Station, TX (Ocean Drilling Program).

${ }^{2}$ Department of Earth Sciences, University of Milano, Italy.
}

recorded also in the central Mediterranean (Bossio et al., 1978) and in the western Mediterranean as well (Cita et al., 1980).

A sharp lithologic change characterizes the Miocene/Pliocene boundary in all the Mediterranean drillsites. The Pliocene transgression records the return of normal marine conditions in the Mediterranean after the Messinian salinity crisis. Sediments of early Pliocene age are carbonate-rich biogenic oozes with a very high plankton/benthos ratio.

Benthic foraminifers are indicative of deep bathyal conditions (Cita, 1973; Wright, 1979). Similar conditions were recorded in all the drillsites where a continous record across the Miocene/Pliocene boundary was documented (DSDP Site 371 and 372 in the Balearic Basin; Site 132 in the Tyrrhenian Basin; Sites 374 and 125 in the Ionian Basin; Sites 375 and 376 in the Levantine Basin; and Site 378 in the Cretan Basin).

Pre-Messinian sediments were recorded at only two drillsites, where the Messinian evaporites pinch out at the edge of the basin margins: Site 372 (Balearic Basin) and Site 375 (Levantine Basin). The open marine, pelagic, bathyal nature of these sediments is considered an important argument supporting the deep basin desiccation model for the origin of the Mediterranean Evaporite (Hsü et al., 1977).

\section{Tyrrhenian Sea}

Our knowledge of Messinian paleoenvironment in the Tyrrhenian, prior to ODP Leg 107, was founded on one drillsite, DSDP 132, which penetrated some $40 \mathrm{~m}$ into the Mediterranean Evaporite and associated clastics.

Several attempts to reconstruct the geometry and facies of Messinian sediments in the Tyrrhenian sea were based on extensive coverage of seismic reflection profiles. Finetti and Morelli (1973) indicate Messinian evaporites throughout the Tyrrhenian, including the southeastern part, where they are thinner than in the west. Fabbri and Curzi (1980) hypothesize a thickness in excess of $1800 \mathrm{~m}$ for Messinian evaporites at the location of DSDP Site 132. They recognize the Upper Evaporites, essentially sulfatic, and the Lower Evaporites with the flowing salt 
layer. An erosional discordance separates these two units in the marginal parts of the basin. Minor evaporites are recognized also in the main southeastern basins (Marsili and Vavilov).

Malinverno et al. (1981) recognize four discrete acoustic facies in the supposed Messinian strata. Facies 1 (evaporitic) is limited to the western Tyrrhenian basin and parallels the Sardinia margin: it is the only one documented by drilling. The remaining facies (2, alluvial-fan deposits; 3 , subaqueous turbidites, probably lacustrine; 4 , erosional surfaces) are attributed to the Messinian by correlation with acoustic facies 1 .

Facies 3 is limited to the deepest, basinal parts of the Tyrrhenian abyssal plain (Marsili and Vavilov basins) whereas facies 2 is recorded along the basin margins.

Rehault et al. (1987) recognize four Messinian facies:

1. Salt basin with diapirs (thickness $400-900 \mathrm{~m}$ ), limited to the western basins, parallel to the Sardinia margin;

2. Salt basins without diapirs $(<400 \mathrm{~m})$ recorded east of the "Faglia centrale" and in the Vavilov basin as well;

3. Marginal-type evaporites $(<200 \mathrm{~m})$ throughout the main abyssal plain; and

4. Fluvial-deltaic type equivalent, limited to parts of the upper Sardinia margin.

These reconstructions differ strongly from one another: they agree only along the western Tyrrhenian margin where the Messinian evaporites are well expressed. This is also the area where the seismic stratigraphy is calibrated to a well.

A sample request for nonevaporitic Messinian strata was submitted prior to the cruise in order to study the supposedly lacustrine sediments to be found in the drillsites located in the abyssal plain.

A special problem to be addressed was the occurrence of the "lago-mare" biofacies, previously unknown from the Tyrrhenian.

\section{MATERIALS AND METHODS}

The material on which the present study is based consist of rock samples of approximately $10 \mathrm{~cm}^{3}$, obtained in 1986 from shipboard sampling of essentially nonevaporitic intervals. Additional samples were obtained a year later, in order to investigate and document the lithologic and micropaleontologic changes across the Miocene/Pliocene boundary at Sites 654, 653, and 652. In all, about 100 samples were studied.

Visual observations were made on a limited number of cores from Site 652 , during a visit by the senior author to the core repository in the fall of 1987.

All the samples received (one per section of each core) were investigated, with the exception of the lower part of Site 652, where only one sample per core was treated, from Core 107-652A-37R to the bottom of the hole.

The most indurated samples were thin sectioned, but the large majority could be disaggregated, washed, and analyzed with the photosedimentograph Analisette 20.

Whenever possible, $5 \mathrm{~g}$ of dried sediment were used. After disaggregation with hydrogen peroxide, the sediment fraction greater than 61 $\mu \mathrm{m}$ was separated, dried, and weighed.

The finer fractions were treated with sodium pyrophosphate, shaken for $1 \mathrm{hr}$, ultrasonically treated for $3 \mathrm{~min}$, and then analyzed with the photosedimentograph Analisette 20 to obtain the percentages of the silt and clay fractions.

The coarse (sand) fraction was then analyzed at the microscope. Visual estimates were made of the various components, and special attention was paid to the biogenic content.

The carbonate content was measured on $1 \mathrm{~g}$ of pulverized sediment using a Dietrich-Friiling calcimeter, with an error of less than $1 \%$.

\section{RESULTS}

The results of our study are presented site by site, starting from the westernmost and shallowest (654), to the easternmost and deepest (656).

\section{Site 654}

Site 654 is located on a tilted block of the eastern Sardinian margin at a water depth of $2208 \mathrm{~m}$. Messinian sediments were recovered from 242.9 to $348.2 \mathrm{~m}$ sub-bottom (2161.1-2566.6 m subsea), but our samples included only lithologic Unit 2.

Fifteen samples were investigated, two of them of early Pliocene (Zanclean) age, the remaining thirteen of Messinian age. Two of the latter group, consisting of siltstones rich in quartz grains, were thin sectioned.

\section{Pliocene (Unit 1)}

The carbonate content of the Pliocene samples is high (in excess of $50 \%$ ) and the grain size is fine, in agreement with the biogenic nature of the sediment (see Fig. 1, above, and Table 1). The sediment is reddish brown.

The topmost sample (107-654-26R-4) is referable to the MPI2 foraminiferal Zone (Cita, 1975a) and contains common benthic species including Siphonina reticulata, Pullenia quinqueloba, Uvigerina peregrina, Cassidulina subglobosa, Brizalina sp., indicative of a mesobathyal environment (Pl. 1-1).

The lowest sample of Zanclean age is practically devoid of benthic forms and belongs to zone MPl1, with abundant Sphaeroidinellopsis, that is typical of this interval.

\section{Messinian (Unit 2)}

The carbonate content of Messinian samples is highly variable, ranging from a minimum of $4.3 \%$ in Core $107-654 \mathrm{~A}-36 \mathrm{R}$ to a maximum of $47 \%$ in Core $107-654 \mathrm{~A}-28 \mathrm{R}$. The grain size is also strongly variable, and reflects the abundance of gypsum, which is high in Cores 107-654-29R-2, 31R, 32R, and 33R (see Table 1). The gypsum is authigenic and occurs in euhedral crystals.

A sharp compositional contrast is observed between the Pliocene sediments and the Messinian ones. The latter are not biogenic, and contain gypsum (Pl. 1-2).

The fossil content is sparse, uneven, and highly variable in composition.

The thin sections and three of the disaggregated samples are barren of fossils. Eight contain microfossils in minor amounts, up to a maximum of $10 \%$. Foraminiferal tests are occasionally pyritized, and pyrite is a common component of the residues. The microfauna has a Miocene character with Globorotalia acostaensis and Globigerina multiloba, and contains shallow-water indicators such as Discorbina sp. and Ammonia beccarii tepida.

An additional nine samples from R. Sprovieri were examined, providing nonquantitative data. Six of these nine samples contain microfossils in variable amounts. In most cases, the planktonic foraminifers are small, sparse and not recognizable. The species Globigerina bulloides, G. bulbosa, G. multiloba, and $G$. quinqueloba could be identified.

The ostracode Cyprideis pannonica agrigentina (Pl. 1-3, Fig. 2A) and the foraminifer Ammonia beccarii tepida (Pl. 1-4, Fig. $2 \mathrm{~B},-\mathrm{C})$, two typical components of the "lago-mare" biofacies, are abundant in Sample 107-654A-28R-4 (33-35 cm) and common in 107-654A-29R-2 (42-44 cm).

These two taxa, which indicate a shallow-water, brackish environment, are limited to the topmost part of the Messinian succession, and were not recorded beneath Core 107-654A-29R. They co-occur with planktonic foraminifers whose environmental requirements are entirely different, and incompatible. Therefore the foraminifers are interpreted as reworked from older marine strata.

\section{Site 653}

Site 653 is located on a flat area called "Cornaglia terrace" very close to DSDP Site 132, and at a similar water depth (2817 m). 


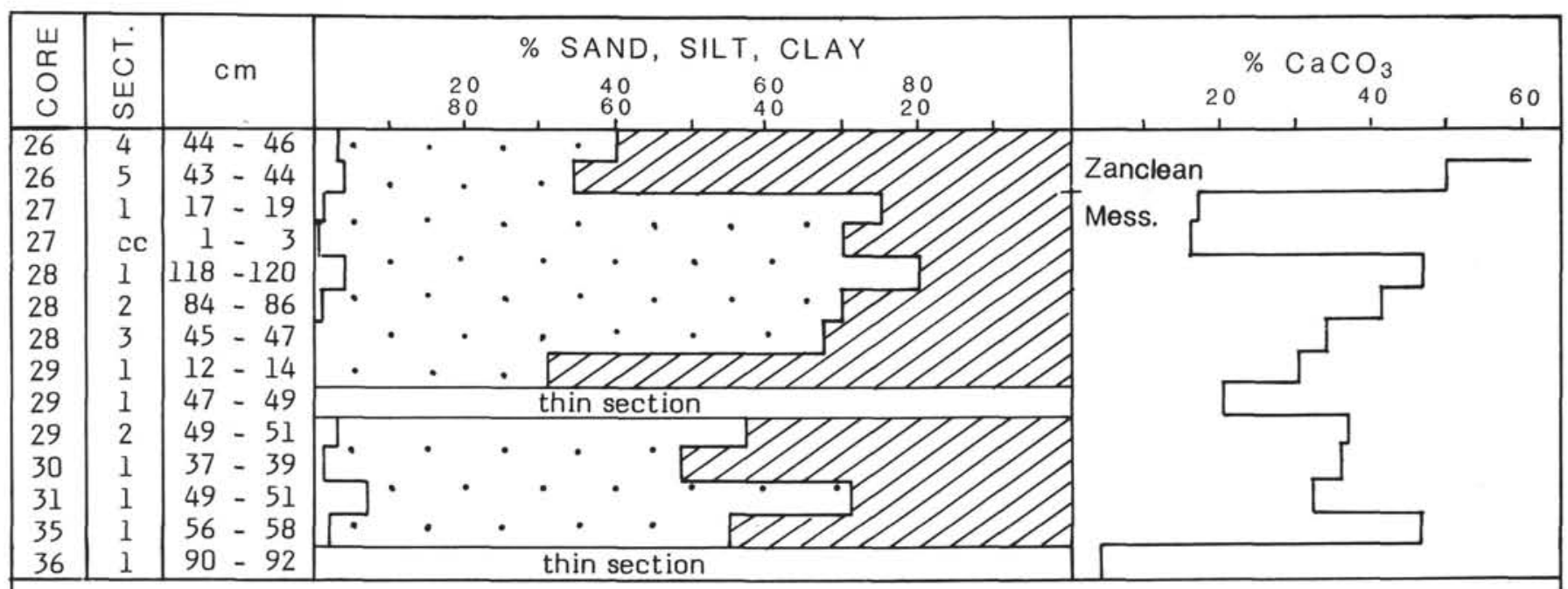

Cores $107654 \mathrm{~A}-26 \mathrm{R}$ to $36 \mathrm{R}$

Figure 1. Grain-size distribution and carbonate content, five selected samples, ODP Site 654 .

Messinian sediments were obtained in Hole 653B from 216.6 to $264.3 \mathrm{~m}$ sub-bottom (3048.0-3095.7 m subsea). Eleven samples were analyzed, two of early Pliocene age (lithologic Unit 1, subunit 1C, 209.1-216.6 m sub-bottom). The remaining nine are of Messinian age (lithologic Unit 2, 216.6-264.3 m sub-bottom). One sample from the Messinian interval was thin sectioned.

\section{Pliocene (Unit 1)}

The carbonate content of the Pliocene samples is high (around $60 \%$ ) and the grain size is fine, in agreement with the biogenic, pelagic nature of the sediment, which is dark brown (Fig. 3). Similar deep hues were noticed in the lowermost few meters of the pelagic succession at nearby Site 132 .

The sand-size fraction in both samples consists essentially of planktonic foraminifers (see $\mathrm{Pl} .2-1,-2$ ) and includes abundant Sphaeroidinellopsis (MP11 Zone). No specimens of keeled Globorotalia were noticed. Benthic forams are extremely rare. The terrigenous components are minor, with small-sized, angular quartz, and iron oxides.

\section{Messinian (Unit 2)}

A sharp lithologic contrast exists between the early Pliocene red marls and the Messinian silts and evaporites. The carbonate content is distinctly lower than in the overlying unit, with a maximum of $24.3 \%$ and a wide range $(0.7 \%-24.3 \%)$ reflecting the variable lithology.

The grain-size distribution confirms the strong variability (see Table 2) of lithologic Unit 2, which is essentially coarsegrained (sand-size up to $62.4 \%$ ) with a few exception $(4.8 \%$ $6.5 \%$ in $107-653 \mathrm{~B}-28 \mathrm{X}$ ). Samples with large sand fraction are associated with two discrete lithologies: terrigenous by derived turbidites, and gypsum.

Plate 2-3 illustrates the two types of residues observed in the samples. Gypsum displays a variety of habits, from tabular to prismatic, with colors ranging from yellow to white, either transparent or opaque. It is observed in plurimillimetric elements in Core 107-653B-25X, CC. Gypsum may also be associated with terrigenous components (see Table 2).

Gypsum-rich samples are usually barren. The only Messinian samples that contain microfossils in some abundance are from the topmost part of the succession (Core 107-653B-24X) and are dominated by terrigenous components. Foraminifers include pelagic and benthic forms. Evidence of reworking is provided by large-sized, abraded Robulus, bryozoan fragments, Ammonia beccarii tepida, Bulimina ovata in Sample 107-653B$24 \mathrm{X}-1,45 \mathrm{~cm}$, and by Elphidium with abraded tests, Discorbis, broken Globorotalia conomiozea in 107-653B-24X-1, $118 \mathrm{~cm}$.

No evidence of the "lago-mare" biofacies was recorded.

\section{Site $\mathbf{6 5 2}$}

Site 652 is located on a tilted block of the lower Sardinian margin and lies northwest of the De Marchi Seamount at a water depth of $3446 \mathrm{~m}$. Sediment $721 \mathrm{~m}$ in thickness was cored with the thickest Messinian succession ever drilled in the Mediterranean (532 m), from 188.6 to $721.1 \mathrm{~m}$ sub-bottom (3653.1$4191.6 \mathrm{~m}$ subsea).

Site 652 is located on the eastern, downthrown side of the "Faglia centrale," not on the western side, as erroneously indicated in the widely distributed documentation concerning Leg 107 (see JOIDES Journal, vol. XII, no. 2, p. 19, Fig. 2, June 1986) and subsequent publications.

The Messinian succession includes two lithologic units, with an additional unit representing a 40 - $\mathrm{cm}$-thick transition between the pelagic facies Pliocene and the terrigenous/evaporitic Messinian.

We analyzed 2 samples from the Pliocene (lithologic Unit 2), 1 from the transitional Unit 3 (Core 107-652A-20R-6, 52-92 $\mathrm{cm}), 36$ from Unit $4 \mathrm{a}$ and $\mathrm{b}$ (Core 107-652A-20R-6, 92-35 cm), none from subunit $4 \mathrm{C}$ (conglomerate, Cores 35-36), 33 from Unit 5a (Cores 107-652A-37R through 72R-2), and 2 from Unit 5 b (Cores $72 R-3$ through 75 ). Subunits $4 a$ and 4 b could not be distinguished on the basis of our sampling and are here lumped together.

Table 3 and Figures 4 and 5 summarize our observational data.

We will comment here separately on (1) the Pliocene samples, (2) the post-conglomerate Messinian, and (3) the pre-conglomerate Messinian.

\section{Pliocene (Unit 2)}

The carbonate content is high (in excess of $50 \%$ ) as recorded in the other drillsites, and the grain-size is fine, in agreement 
Table 1. Distribution of detrital minerals, authigenic minerals, and biogenic components in the samples investigated from Hole 654A (upper Sardinia margin).

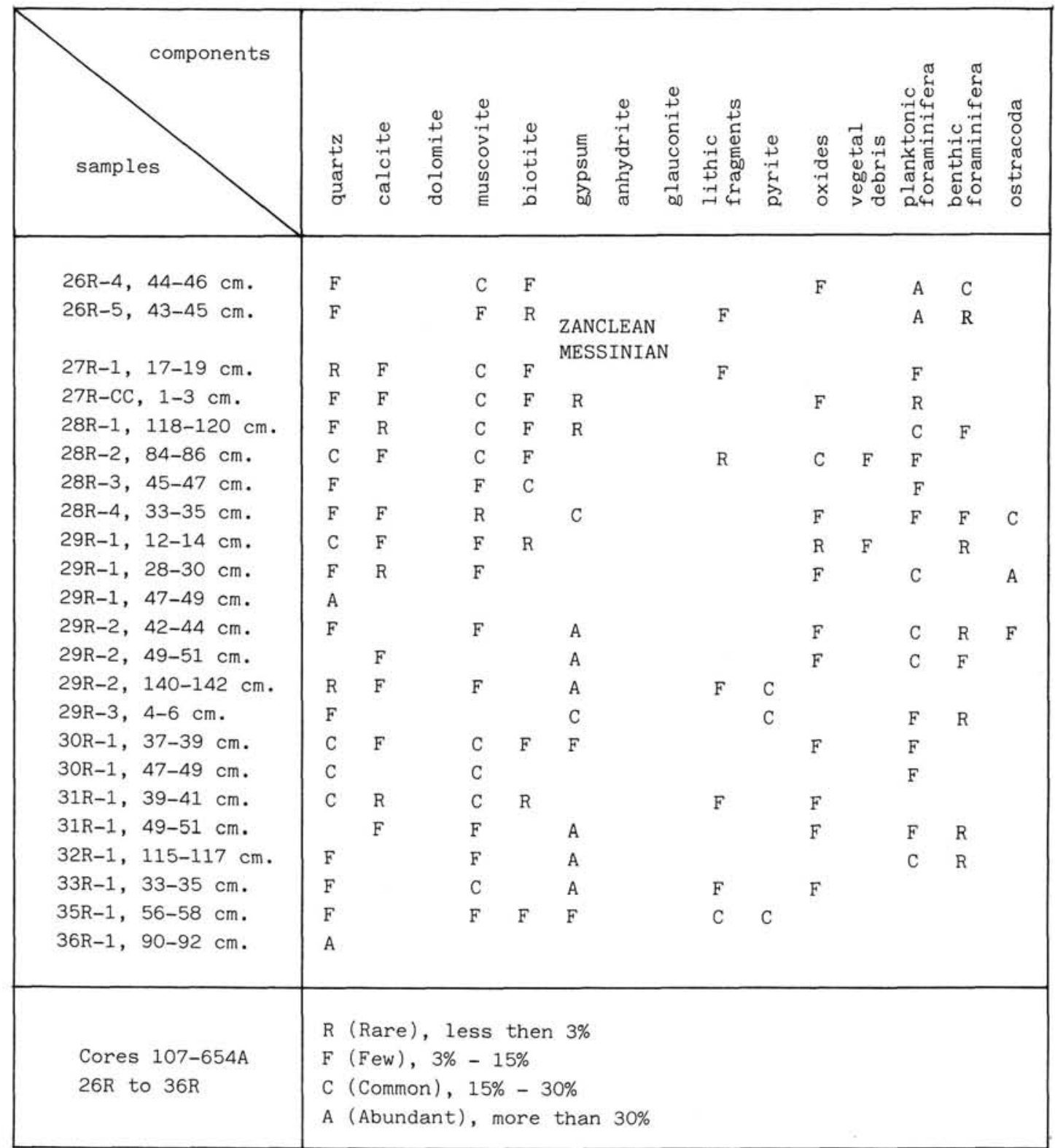

with the biogenic, pelagic nature of the sediment. Here as in the western drillsites, the sediments are dark. The abundance of iron oxides is considered the result of Pliocene removal and accumulation of the products of subaerial oxidation during the latest stages of the Messinian.

The sand-size fraction is biogenic and pelagic, dominated by planktonic foraminifers (Pl. 3-1) with abundant Sphaeroidinellopsis (MPI1 Zone), some G. scitula, Globigerinoides obliquus obliquus, G.obliquus extremus and others, and no keeled Globorotalia. The only benthic species identified is the deep bathyal form Eponides tumidulus.

\section{Miocene-Pliocene transition (Unit 3)}

This lithologic unit was created for a $40-\mathrm{cm}$ interval consisting of alternating decimetric layers of red marls (identical to those of the early Pliocene) and of fine-grained pale green-gray silts and muds. We obtained one sample from the latter lithology (see $\mathrm{Pl} .3-2$ ). The residue is small, fine grained and almost barren, containing only rare planktonic foraminifers with Globorotalia acostaensis, Orbulina universa, and Globigerina bulbosa. The carbonate content is one fifth of the Pliocene values, and iron oxides are common.

\section{Messinian Post-conglomerate (Unit 4)}

The carbonate content is distinctly lower than in the Pliocene, ranging from approximately $10 \%$ to $30 \%$. The grain-size is highly variable, the silt fraction being dominant in most samples.

Sand ranges from a few per mil to over $10 \%$ (Fig. 4, Pl. 3-3 and -4 ).

The biogenic content is scattered, discontinuous, and inconspicuous. Displaced benthic foraminifers are occasionally present. 


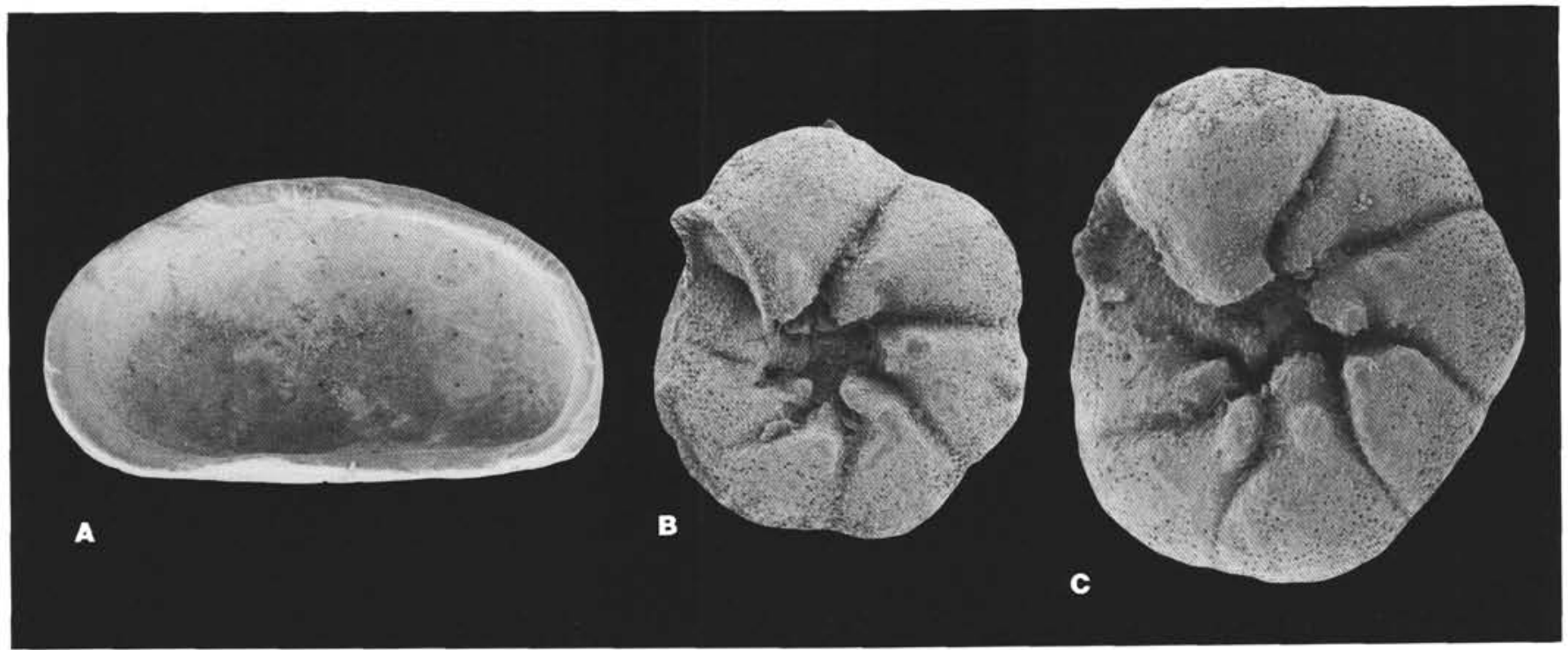

Figure 2. Cyprideis pannonica agrigentina. A. Interior view of a dextral male valve. Notice the hinge zone and the well developed pore canals. $\times 65$. B, C. Ammonia beccarii tepida. Umbilical views. $\times 144$. All the specimens are from Sample 107-654A-28R-4, 33-35 cm.

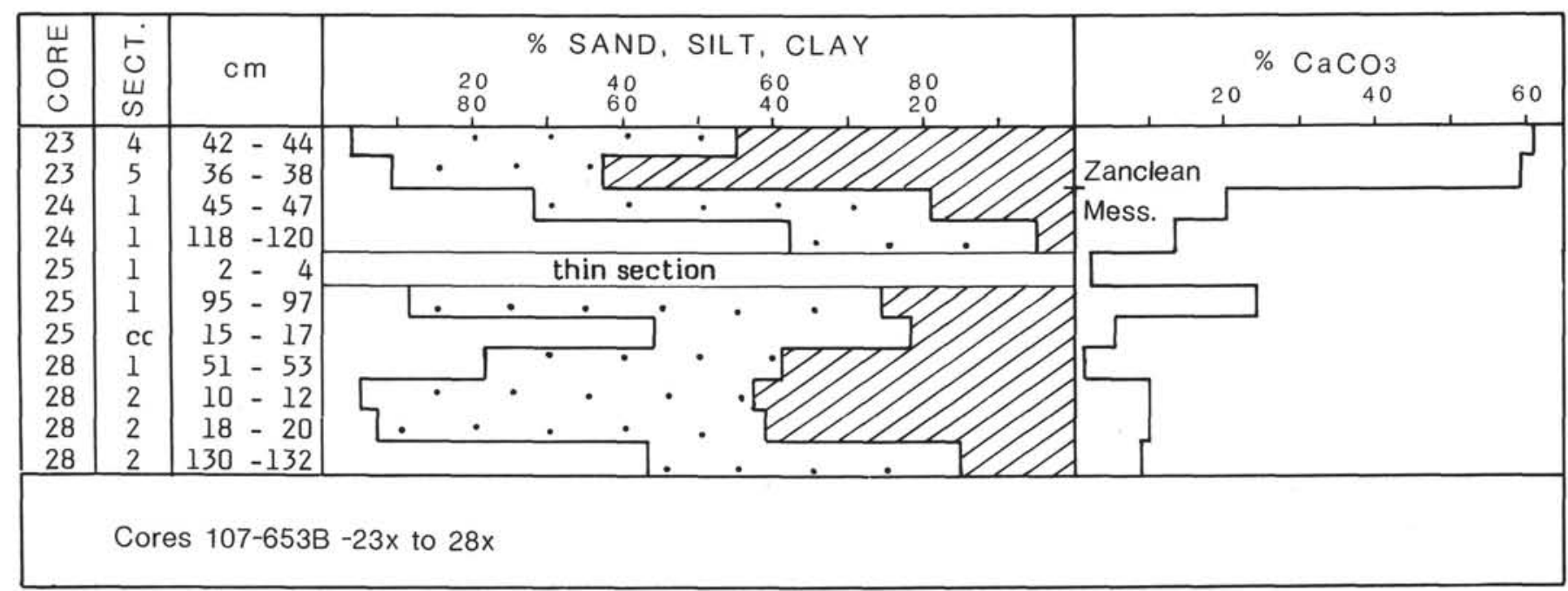

Figure 3. Grain-size distribution and carbonate content, selected samples, ODP Hole 653B.

Small-sized planktonic forms were observed as far down as Core 107-652A-27R but no deeper. Plant debris were recorded in five samples, and also occasional spores of Tasmanites.

Gypsum is never abundant, and is detrital in origin. The sediments are not bioturbated. A coarse-grained turbidite with truncated surfaces was observed in Core 107-652A-33R-3.

Samples from Core 107-652A-33R through 35R were examined in thin section. They consist of hybrid siltites fairly rich in carbonates that are partly detrital, partly recrystallized. Quartz is a common constituent followed by gypsum, feldspar, rare glauconite, and mica in variable amounts. No microfossils were recorded in any of the thin sections.

\section{Messinian Pre-conglomerate (Unit 5)}

Only one sample per core was analyzed from this unit. The lowermost part of the unit, from Core 107-652A-72R-2 to the bottom of the hole, is separated as subunit $5 \mathrm{~b}$ on the basis of induration.
The carbonate content is fairly high, ranging from a few percent to $40 \%$ (the average of 35 measurements is $21 \%$ ). The grain size is highly variable (see Table 3 , Fig. 5 ) but the silt fraction is consistently the largest sediment fraction.

Seven gypsum cycles were identified shipboard: three cycles in Cores 107-652A-37R to 44R, one in Core 107-652A-47R, one in Core 107-652A-54R, one in Cores 107-652A-60R to 62R, and one in Core 107-652A-70R, but these cycles do not show up in the parameters considered here. Gypsum is never a dominant constituent of the sand-size fraction, with a few exceptions (see Pl. 4). Gypsum is either detrital or authigenic. Other lithologic characters that we were not able to document in our samples are the presence of organic-carbon-rich algal layers in the central part of the unit, and the anoxic character of the lower interval.

The biogenic components are sparse and scattered, if not absent altogether. They consist of (1) plant debris and (2) smallsized planktonic and/or benthic foraminifers (see Pl. 4-4). No evidence of the "lago-mare" biofacies was recorded in our sam- 
Table 2. Distribution of detrital minerals, authigenic minerals, and biogenic components in the samples investigated from Hole 653B (Cornaglia terrace).

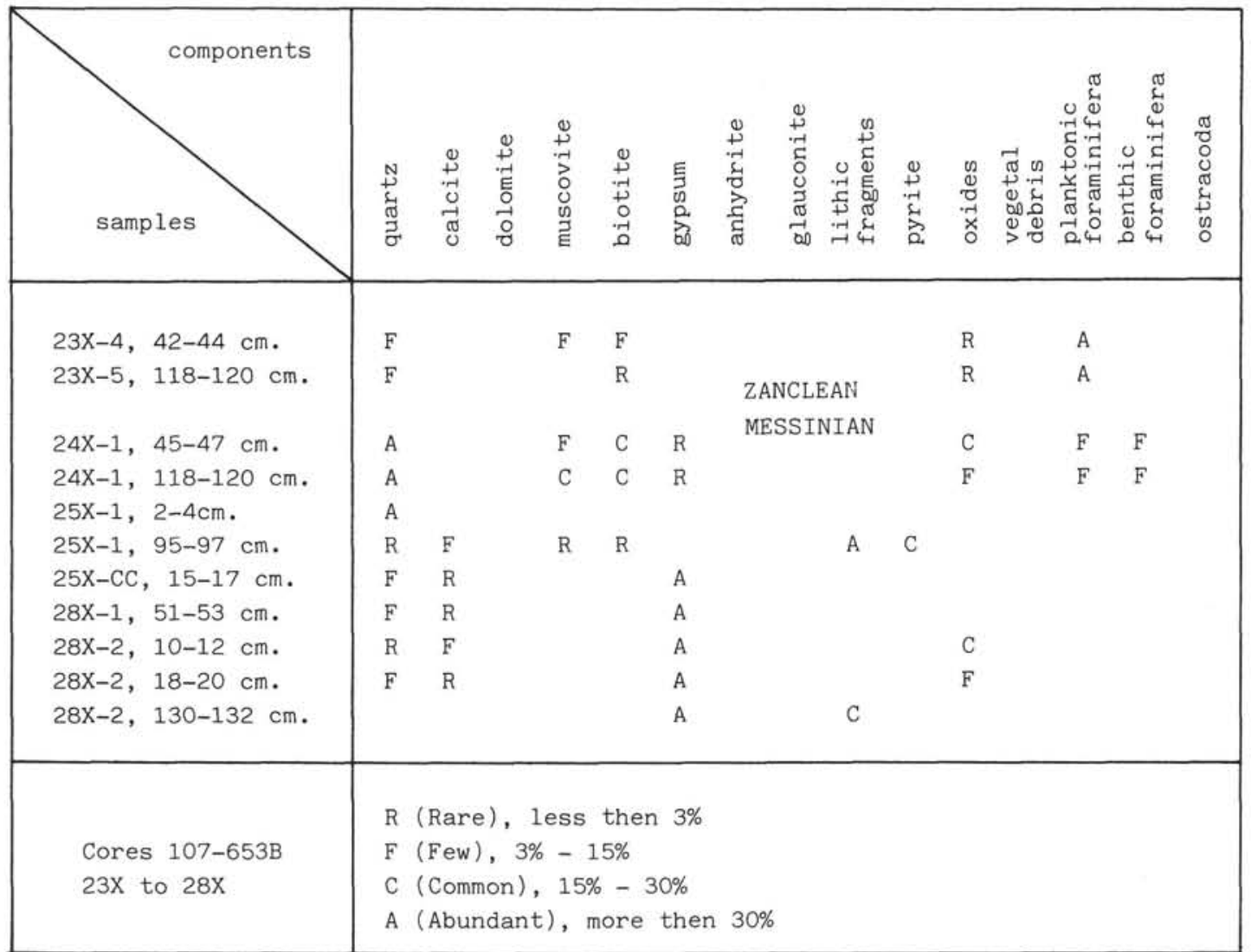

ples, and there is no evidence of conspicuous reworked faunas. In other Mediterranean drillsites where strong and clear evidence of reworking was noticed in Messinian clastics, as at DSDP Site 376 , microfossils were locally very abundant and size-selected. They included large specimens, planktonic foraminifers of various ages, and benthic foraminifers of various habitats (Cita et al., 1978). A few specimens of marine microfossils were recorded in 14 of the 35 samples; all are small-sized, suggesting some marine influence in an essentially nonmarine, subaqueous environment (lacustrine).

The distinction we propose for this thick pre-conglomerate unit based on our observational data (consisting of (1) carbonate content, (2) grain-size, (3) composition of the sand fraction, and (4) biogenic content) is presented here and will be discussed later on, as a basis for a tentative "event stratigraphy" interpretation.

\section{Subunit Alpha}

Cores $107-652 \mathrm{~A}-37 \mathrm{R}$ to $45 \mathrm{R}$ are characterized by a fairly high carbonate content (mean 26\%) and a dominance of the silt fraction $(60 \%)$.

The coarse fraction consists of associated gypsum and anhydrite or calcite, alternating with siliciclastic intervals. Gypsum and anhydrite are most abundant in this interval: they may be authigenic or detrital. The biogenic content is extremely scarce.

\section{Subunit Beta}

Cores $107-652 \mathrm{~A}-45 \mathrm{R}$ to $50 \mathrm{R}$ are characterized by alternating silt and sandy silt with strong oscillation of the carbonate content $(13 \%-38 \%)$. The sand fraction is essentially clastic and contains gypsum and minor anhydrite, with abundant carbonates (calcite or dolomite).

Gypsum is mainly detrital. Glauconite is persistently recorded, although not abundant. The biogenic content is very limited, with plant debris and small-sized, sparse planktonic foraminifers.

\section{Subunit Gamma}

Cores $107-652 \mathrm{~A}-51 \mathrm{R}$ to $60 \mathrm{R}$ are characterized by silty sands passing downhole into clayey silts with carbonate content ranging from $8 \%$ to $30 \%$. The coarse fraction consists primarily of calcite-cemented aggregates of gypsum, calcite, quartz, and glauconite, probably detrital, and by iron oxides (hematite of sedimentary origin) (Pl. 4-1) and authigenic gypsum (Pl. 4-2) at the bottom of the interval. The dominant color of the sediment samples is brown (indicative of good oxygenation).

\section{Subunit Delta}

Cores $107-652 \mathrm{~A}-61 \mathrm{R}$ to $65 \mathrm{R}$ are characterized by a dominant blackish color, low carbonate content $(12 \%)$, and the occurrence of authigenic pyrite (Pl. 4-3) which was conspicuously absent higher in the section. Primary gypsum crystals were recorded, co-occurring with pyrite. Microfossils, although always sparse, are relatively more abundant in this interval (Pl. 4-4), and suggest a stronger marine influx.

\section{Subunit Epsilon}

Cores $107-652 \mathrm{~A}-66 \mathrm{R}$ to $75 \mathrm{R}$ are characterized by fairly constant carbonate content around $21 \%$. The sand fraction increases downhole and the dominant mineral is gypsum. Gypsum is recorded in laminae in the upper part of the unit and in subrounded clasts lower in the section. 
Table 3. Distribution of detrital minerals, authigenic minerals, and biogenic components in the samples investigated from Hole 652A (lower Sardinia margin).

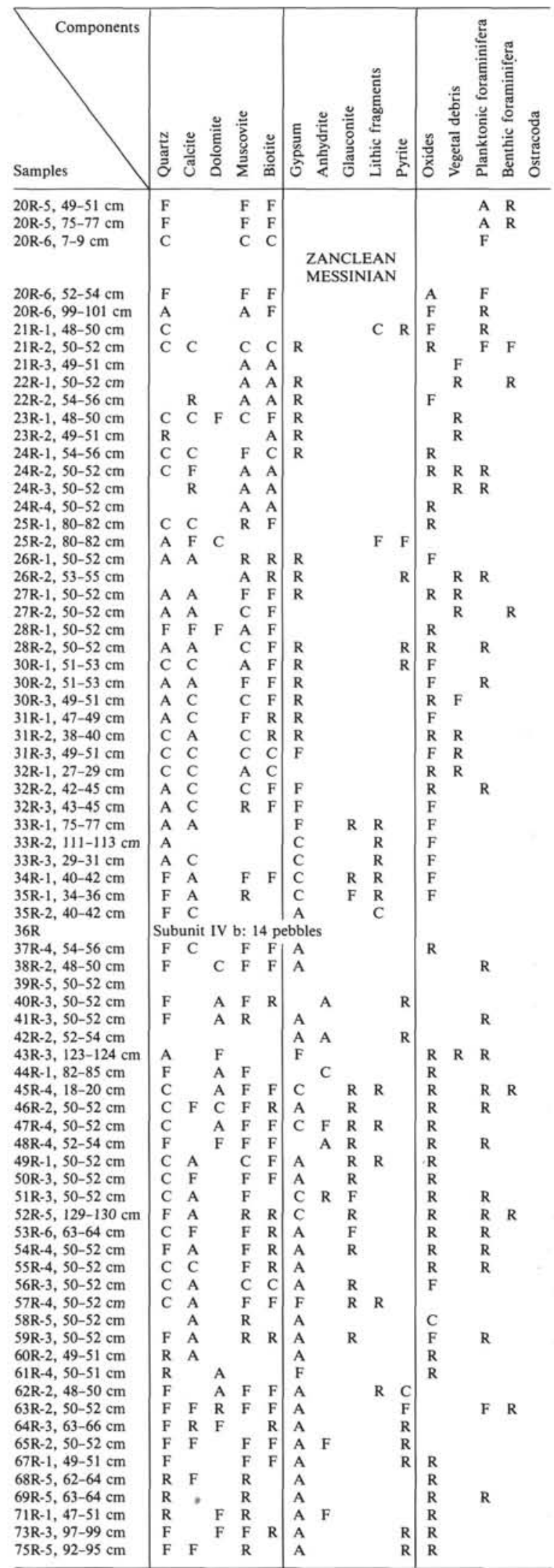

Note: Cores 107-652A-20R to 75R: R (Rare), less than 3\%; F (Few), 3\%-15\%; C (Common), 15\%-30\%; A (Abundant), more than $30 \%$.
The lowermost three cores (107-652A-71R, 73R, and 74R) are strongly indurated. The dominant color is dark grey. They were thin-sectioned. The hybrid siltites display a banded structure and are graded from sandy siltstones to micrites.

In the coarser fractions quartz, calcite, and gypsum are recorded as individual crystals, or as recrystallized areas. No fossils were noticed.

\section{Site 656}

This site is located on the western flank of the De Marchi Seamount, the lowermost tilted block of the Sardinia margin, slightly southeast of Site 652 and at a water depth of $3597 \mathrm{~m}$.

Pre-early Pliocene terrigenous sediments of presumably Messinian age were recovered from 169.7 to $179.1 \mathrm{~m}$ sub-bottom (3775.7-3785.1 m subsea) in Hole 656A (lithologic Unit 3).

These sediment overlie a $57.3 \mathrm{~m}$ coarse-grained unit (lithologic Unit 4) that includes numerous clasts indicative of a continental basement. The latter unit is also considered of probable Messinian age, and indicative of a subaerial environment (Kastens, Mascle, et al., 1987).

Two samples were obtained from Unit 3. Their grain-size, carbonate content, and composition of the sand-size fraction are indicated in Figure 6.

Gypsum was consistently recorded, as tabular and/or prismatic crystals. Planktonic and benthic foraminifers are sparse, small-sized, size-selected, and probably reworked.

No evidence of "lago-mare" biofacies was recorded.

\section{DISCUSSION AND CONCLUSIONS}

A great surprise provided by this ODP Leg was the absence of Messinian-age sediments in the Tyrrhenian abyssal plain (Marsili and Vavilov Basins). The terrigenous, lacustrine facies supposedly present there (Malinverno et al., 1981) were only recorded at the westernmost edge of the basin, on the lower tilted blocks of the eastern Sardinia margin. Site 652 presents several problematic aspects both in terms of stratigraphic interpretation and of geodynamic implications and will be discussed last. The other drillsites essentially confirmed the previous knowledge of Messinian paleogeography and paleoenvironment.

Among these, the shallowest site (654) is of special interest because the following features were noticed for the first time:

1. The transition from evaporites to the pre-evaporitic, euxinic, high productivity environment,

2. No substantial sedimentary gaps, unlike at DSDP Sites 372 and 375 ,

3. The Tortonian/Messinian boundary was recovered within a continuous marine succession, and

4. The "lago-mare" biofacies could be documented in the deep-sea record of the western Mediterranean. As in the eastern Mediterranean, the biotope is restricted to the topmost part of the Messinian succession.

Other findings that support the previous information and interpretations concern the Miocene/Pliocene boundary as defined by Cita (1975 b):

1. A sharp lithologic contrast was noticed in all the drillsites investigated $(654,653,652)$ between the early Pliocene (Zanclean) pelagic oozes and the late Miocene (Messinian) terrigenous, gypsiferous silts,

2. The early Pliocene pelagites indicate a deep, bathyal environment, as supported by the very high plankton/benthos ratio, the limited diversity of the benthic fauna, and its composition,

3. Although our observational data are limited, it is clear that the present bathymetry generally reflects the earliest Plio- 


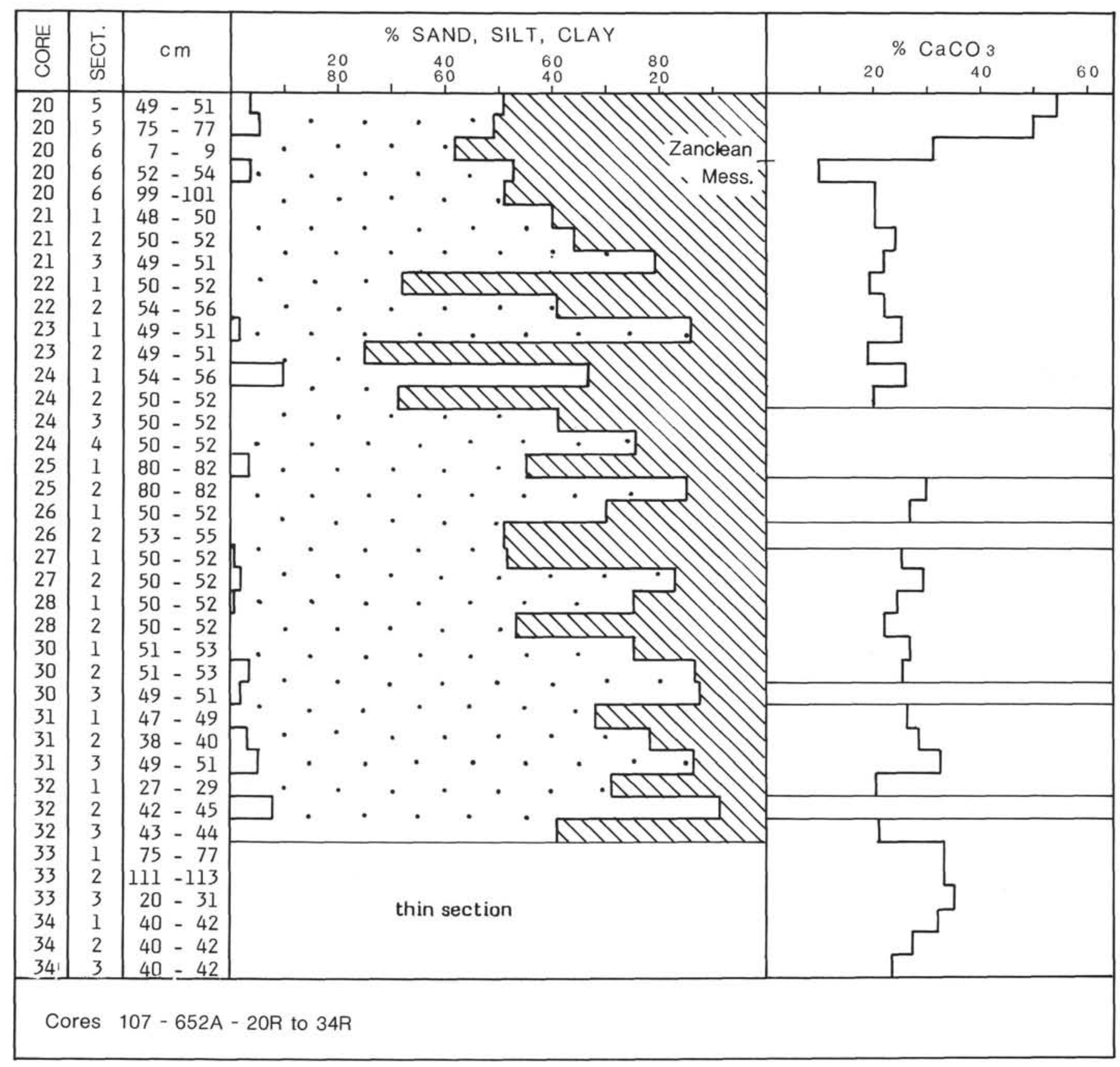

Figure 4. Grain-size distribution and carbonate content, selected samples, ODP Site 652 (Cores 107-652A-20R-5 to 34R-3).

cene paleobathymetry: benthic foraminifers are more abundant, and include taxa with a shallower habitat high on the slope (Site 654 , water depth $2208 \mathrm{~m}$ ) than on the Cornaglia Terrace (Site 653 , water depth 2817) or at the base of the slope (Site 652, water depth 3446), and

4. Red hues were consistently noticed in the basal Pliocene strata, as previously recorded in the Tyrrhenian DSDP drillsite 132 , but not in any other Mediterranean drillsite. The abundance of iron oxides suggestive of removal from subaerially exposed terranes in a well oxygenated environment should be related to the route followed by the Atlantic water masses invading the Tyrrhenian basin at the termination of the Messinian salinity crisis: exposures of karstified limestones on a sill separating Sicily from Sardinia could be responsible for the observed phenomenon.

\section{Stratigraphy of Site 652}

The supposedly Messinian, pre-Pliocene succession is very thick $(530 \mathrm{~m})$, essentially terrigenous, with minor evaporites, and very monotonous. Heat flow measured at this site is very high, and is considered responsible for some diagenetic changes undergone by the sulfates (Kastens, Mascle, et al., 1987).

The sedimentary succession is essentially barren, and the (near) absence of marine fossils is a strong argument in favor of a nonmarine environment. No evidence of subaerial exposures was recorded. The regularly stratified nature of the sediments, the occurrence of laminated intervals, and frequent turbidites suggest a permanently subaqueous setting. A lacustrine environment is proposed, in agreement with the shipboard interpretation. 


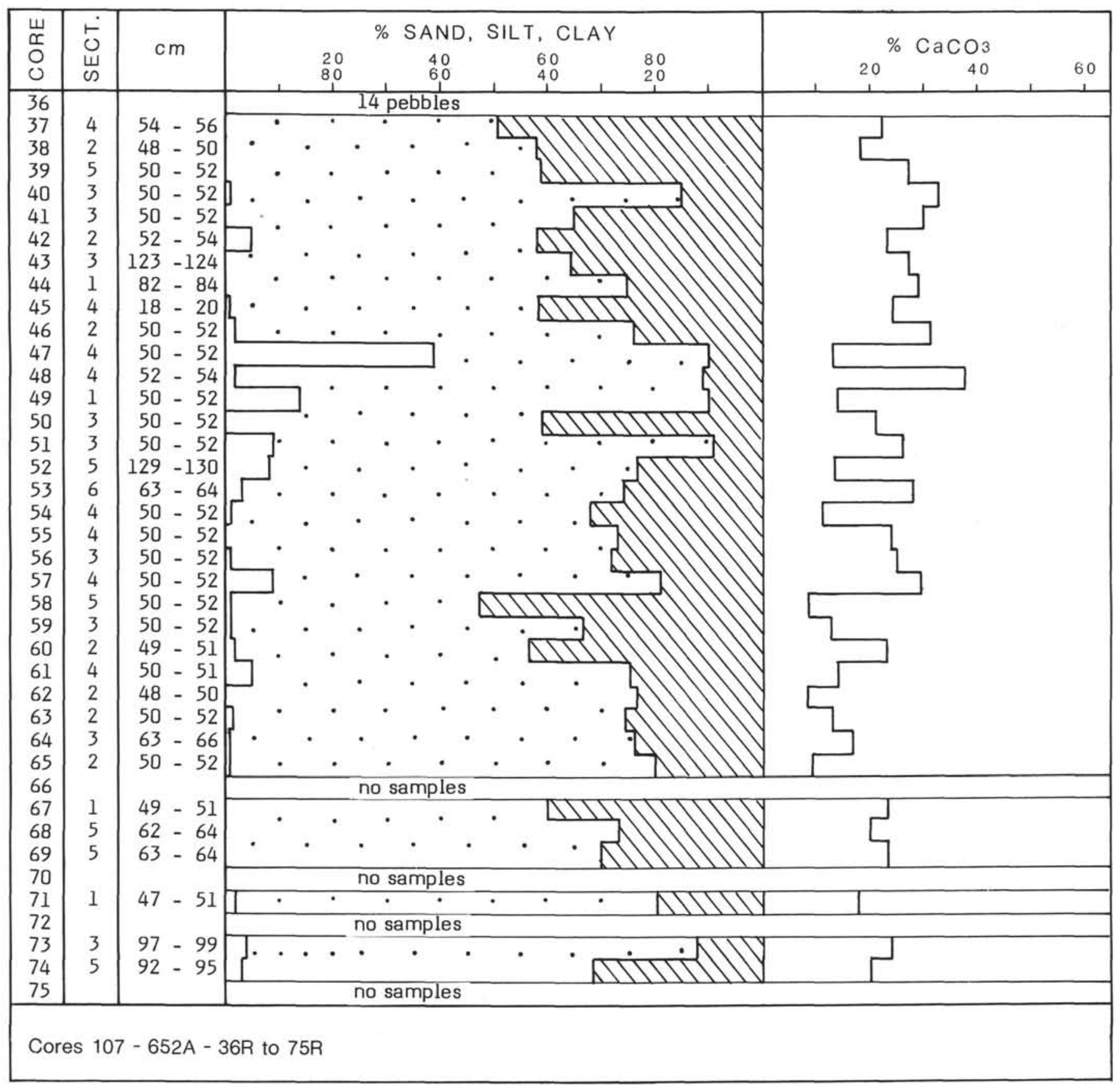

Figure 5. Grain-size distribution and carbonate content, selected samples, ODP Site 652 (Cores 107-652A-37R-4 to 74R-5).

The scattered occurrence of sparse, small-sized foraminifers in the pre-conglomerate interval is interpreted as an indication of temporary marine incursions more than of reworking from older marine formations, exposed on the basin margins. No age diagnostic fossils are encountered.

Under those circumstances, the succession cannot be dated biostratigraphically.

It cannot be dated lithostratigraphically either, because of its monotonous nature, and absence of marker beds, with the exception of the conglomerate recorded in Core 107-652A-36R which cannot be correlated with any Mediterranean drillsite, anyway.

If "event stratigraphy" is an acceptable tool to decipher a complex sedimentary history that cannot be deciphered with more obvious, and classic tools, then we propose the following stratigraphic interpretation from top to bottom (see Fig. 7):

1. The post-conglomerate interval (Cores 107-652A, 27R to 35R; lithologic Unit 4a-b) correlates with the Upper Evaporites and post-evaporitic episode;

2 . The conglomerate (Core 107-652A-36R; lithologic Unit 4c) corresponds to the erosional discordance noticed by Fabbri and Curzi (1980) on the Tyrrhenian basin margin;

3. The pre-conglomerate interval (Cores 107-362A-37R to 60R; lithologic Unit 5; our subunits alpha, beta and gamma) which includes the levels where sulfates are more abundant, correlates with the Lower Evaporites; 

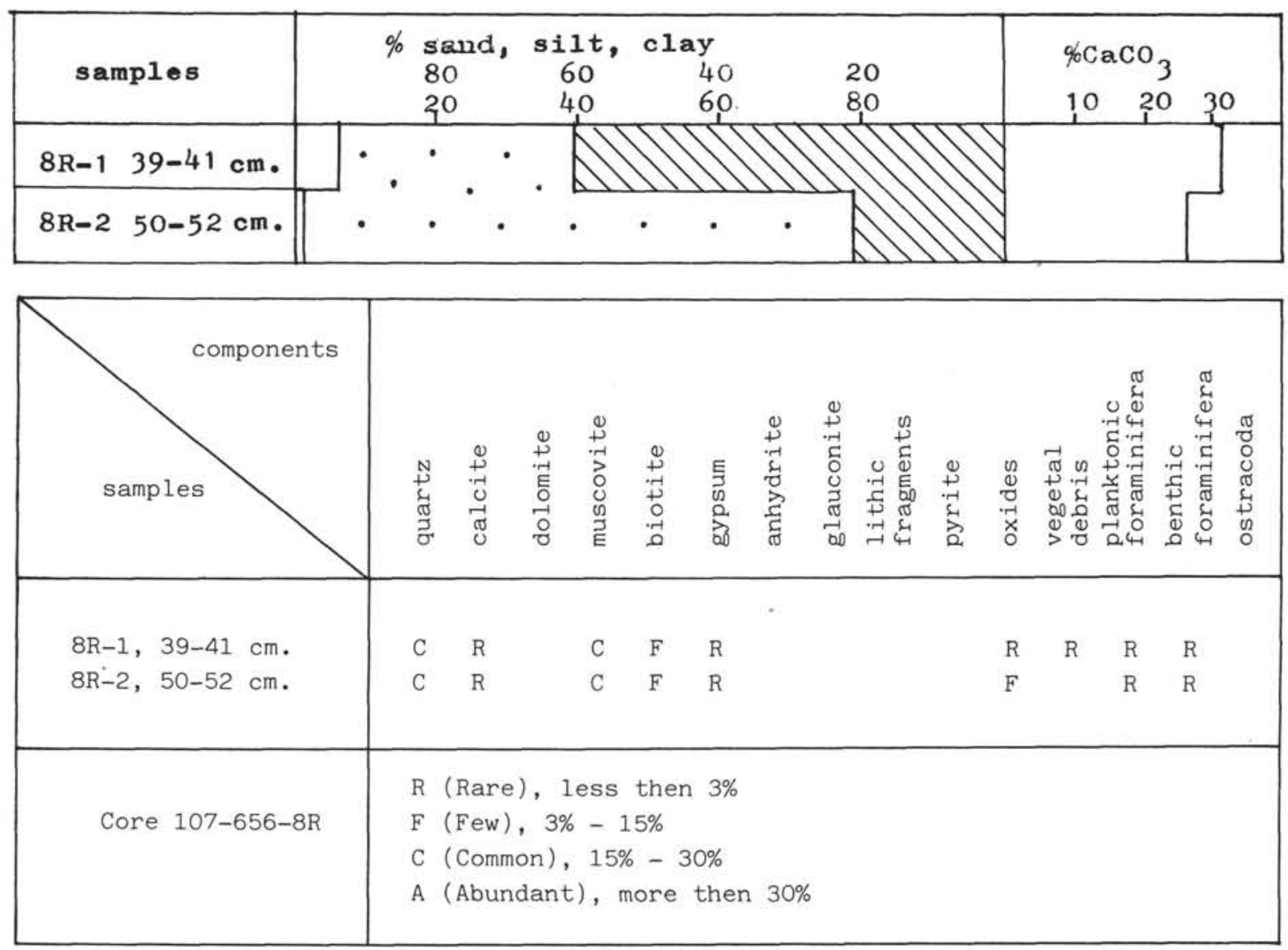

Figure 6. Grain-size distribution and carbonate content, selected samples, ODP Site 656.

4. The pre-conglomerate interval (Cores 107-652A-61R to $65 \mathrm{R}$; lithologic Unit 5; our subunit delta) might be correlatable with the Tripoli preevaporitic interval. The poorly oxygenated nature of the sediments and the occurrence of frequent laminae suggest a similar environment, although in an essentially nonmarine situation;

5. The lowermost part of the succession (Cores 107-652A$67 \mathrm{R}$ to $75 \mathrm{R}$; our subunit epsilon) might correlate with the basal Messinian, and eventually extend into the late Tortonian, but this correlation is very tentative.

In other words, the terrigenous (with minor evaporites) succession penetrated at Site 652 should correspond to the entire Messinian, and correlate with Cores 107-652A-27R to $40 \mathrm{R}$ at Site 654 .

This interpretation is in good agreement with the clay mineralogy (Chamley et al,, this volume; Broglia et al., this volume). A high smectite content was consistently recorded above the conglomerates, but not underneath. In Sicily (Chamley and Robert, 1980), smectites are a typical component of the latest Messinian strata, whereas lower in the succession, the mineralogical composition is more varied, reflecting the local environment.

According to this interpretation, the term "lago-mare," which is historically tied to a peculiar biotope occurring in the latest part of the Messinian salinity crisis, should not be applied to the entire succession.

The stratigraphic interpretation discussed above disagrees with the paleomagnetic stratigraphy of Site 652 , as presented by Kastens and by Channell et al. (this volume) and Mascle et al. (this volume). According to these authors, the entire pre-Pliocene succession is attributed to the lowermost reversed interval of the Gilbert Chron, with a numerical age younger than 5.35 m.y., due to the consistently reversed remanent magnetization measured in the sediments.

The paleomagnetic study carried out at Site 652 as well as that carried out at Site 654 (Channell, Rio, et al., this volume) are the first attempts to work out the paleomagnetic stratigraphy of the Messinian in the Mediterranean. Previous attempts to interpret and correlate Messinian events recorded in the Mediterranean with the paleomagnetically calibrated open marine record were provided by Cita (1982), McKenzie and Oberhansli (1985), Cita and McKenzie (1986), and Muller and Hsü (1987). Although differing in some details, they all concur in extending the Messinian throughout Chron 5, which is mostly normally magnetized and extends well beyond 5.35 m.y.

We are aware that our interpretation and Channell's interpretation are incompatible. Nevertheless, we insist on our proposition, suggesting a revision of the paleomagnetic data for the following reasons:

1. An interval encompassing Cores $107-652 A-62 R$ and $63 R$ is characterized by normal magnetization (Channell and Thorii, this volume), thus allowing a different interpretation of the data;

2 . The strong diagenesis affecting the sediments from the lower part of Site 652 (see several other papers on organic geochemistry, clay mineralogy, and diagenesis, all in this volume) is attributed to the high heat flow. This diagenesis might have affected the magnetic properties of the sediments under discussion. But no special studies on magnetic properties were carried out (Channell, pers. comm.); 


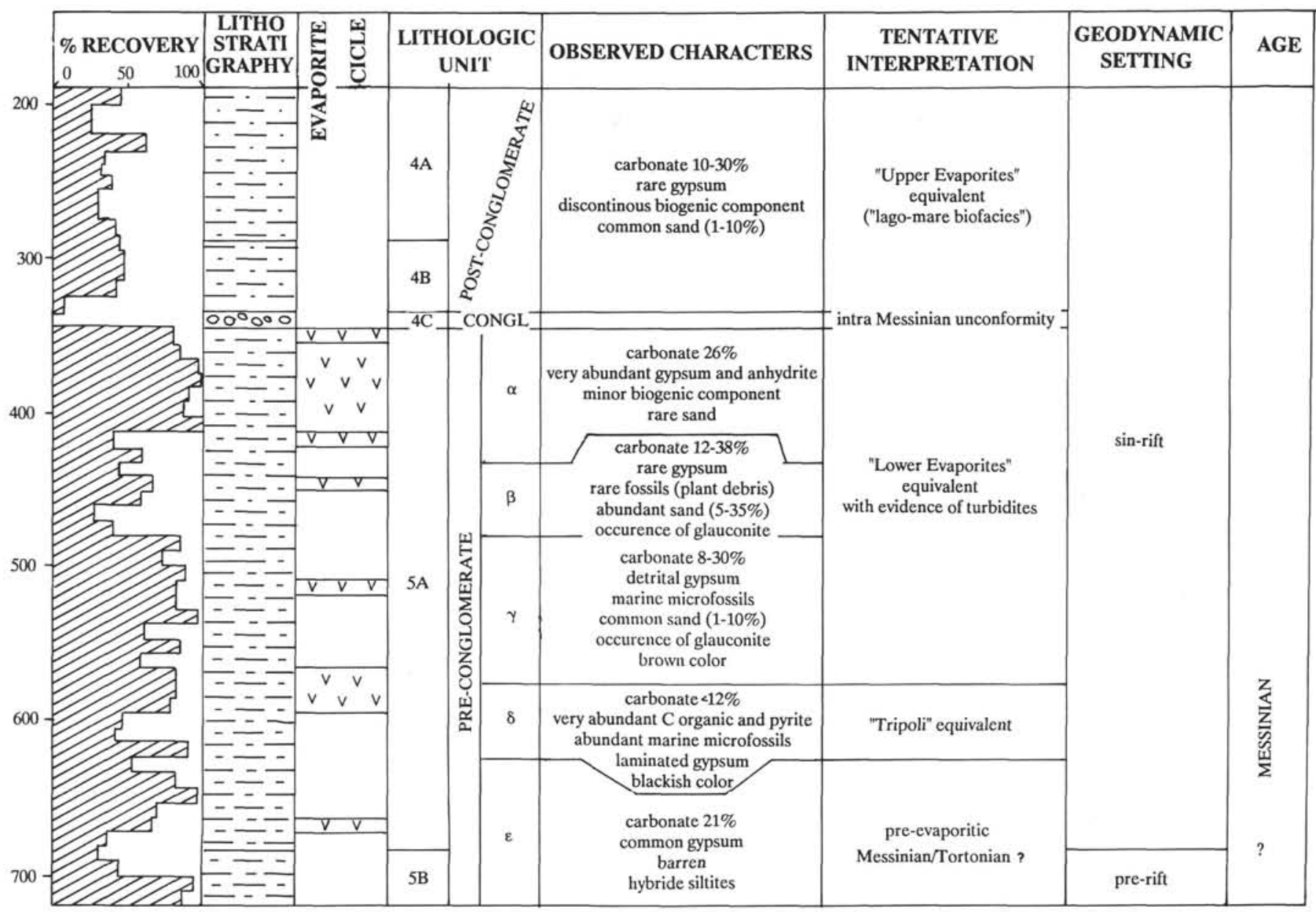

gypsiferous sediments with claystone, mudstone, siltstone or sandstone

$0:$ conglomerate pebbles

evaporites

Figure 7. Comparison of the subdivision of the pre-Pliocene succession recovered at ODP Site 652 (left, by Shipboard Scientific Party) and of the subdivision proposed here (right). Our stratigraphic interpretation is also shown.

3. The conglomeratic Unit $4 c$ corresponds to a major unconformity which is well detectable on the seismic lines (Mascle and Rehault, this volume). A part of the stratigraphic record might be concealed by this unconformity.

The interval that we tentatively correlate with the "Tripoli" Formation (our subunit delta) is reversely magnetized at Site 652 , while the corresponding unit is normally magnetized at Site 654 (Channell, Rio, et al., this volume).

Again we are not impressed by this discrepancy for argument 3. Also, core recovery at Site 654 was around $50 \%$, too low to allow a fine and reliable paleomagnetic calibration.

\section{Geodynamic Setting}

Site 652 is located on the flank of a tilted block on the lower continental margin, on the downthrown side of the important tectonic lineament called "Faglia centrale" (Selli, 1970). The surficial expression of the eastward dipping throw is of some $700-800 \mathrm{~m}$. The age of this fault is considered pre-Messinian by Fabbri and Curzi (1980) and by Malinverno et al. (1981) on the basis of seismic stratigraphic arguments.

A comparison of the Messinian succession recovered at Sites 653 and 652 (Fig. 8), which are approximately $30 \mathrm{~km}$ apart does not support this interpretation, or at least requires significant post-Messinian reactivation of the fault. A two stage modelling of the Sardinia margin is proposed by Genesseaux (1986) on the basis of visual observations with the submersible Cyana. He found evidence of important tectonic activity and of subaerial erosion in Messinian times followed by post-Messinian normal faults especially well expressed on the lower slope.

Indeed, the Messinian brine pools originating the thick evaporites deposited beneath the Cornaglia Terrace should lie at lower depths than the rapidly subsiding lake where the turbidites accumulated at a fast rate, with occasional marine incursions (Site 652, see Fig. 8C, -D). Even if an intervening basement high or ridge could act as a barrier, preventing an eastward diffusion of the brines, which were obviously fed from the south, we cannot conceive that the lake was much deeper than the brine pool, even if seepage was subterranean.

A coherent facies trend was documented across the continental margin west of Sardinia, facing the Balearic abyssal plain (Ryan, Hsü, et al., 1973, Fig. 21) from playa salt in the abyssal plain (Site 134B) to intertidal and supertidal anhydrite on a basement high (Site 134) to subaerial flood plain gravels higher on the slope (Site 133). This facies trend was used as an argument in support of the deep basin desiccation model (the vertical relief predated the salinity crisis).

No such coherent facies trend is recorded across the opposite continental margin of Sardinia, facing the Tyrrhenian abyssal plain. 


\section{Secchi}
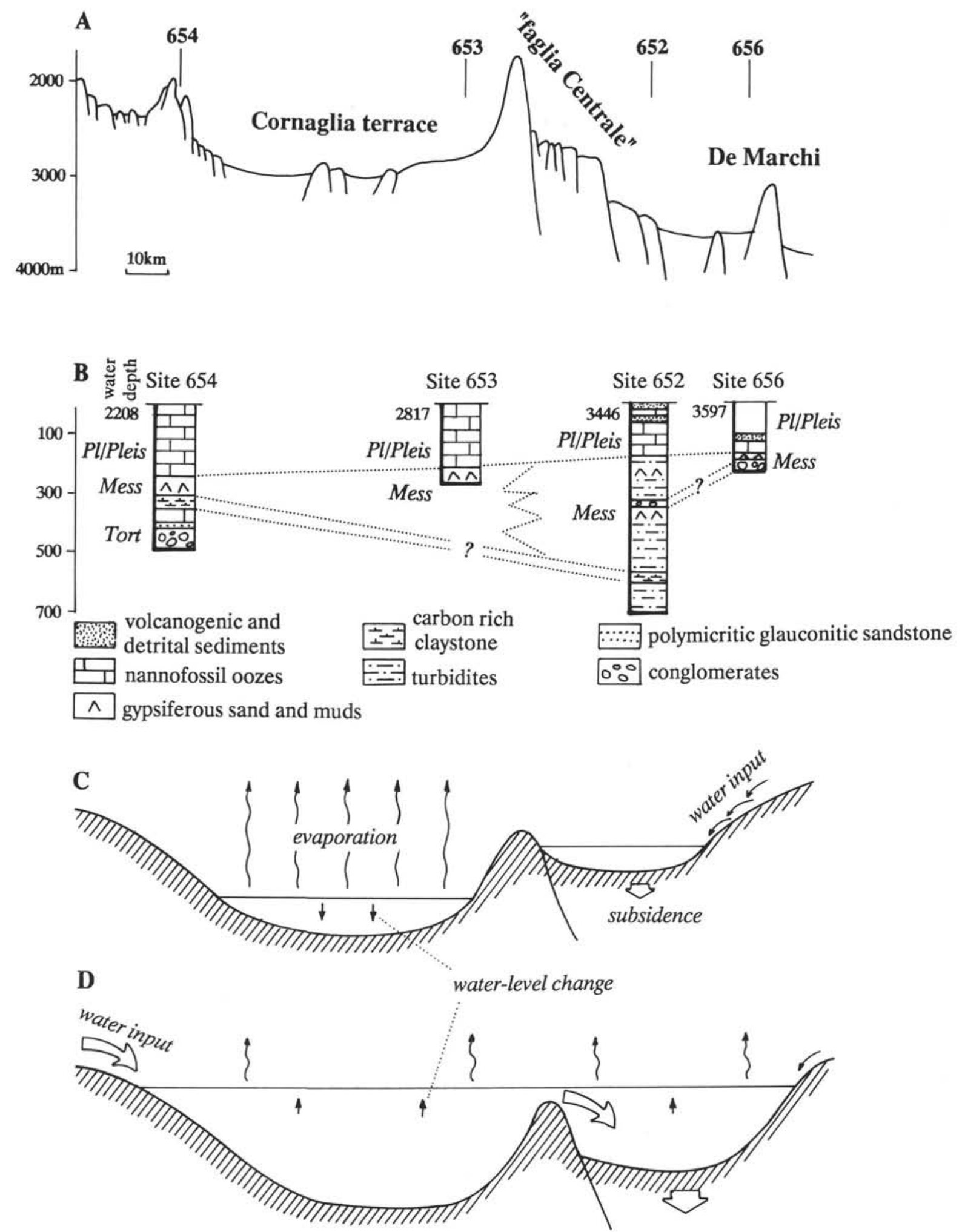

Figure 8. Simplified bathymetric profile across the eastern Sardinia margin. A. Location of drillsites. B. Recovered stratigraphic succession. The sketches illustrate our interpretation of the Tyrrhenian Basin in Messinian times, when the Mediterranean was disconnected from the Atlantic and displayed different water levels, as exemplified by $\mathbf{C}$ and $\mathbf{D}$. C. The depocenter of the evaporitic basin was situated beneath the Cornaglia Terrace: Site 653 was in this area, whereas Site 654 , which represents a reduced evaporitic series, was located higher on the slope. A basement ridge separated the evaporating pond that was fed by marine waters from the south or southwest, from a rapidly subsiding water body (Site 652) on the opposite side of the basin. D. This lake, where subaqueous turbidites accumulated rapidly, was fed by continental waters from the east and northeast, with occasional marine incursions when the level of the evaporitic pond was higher than the basement ridge. 
Using the same philosophy, one should conclude not only that the vertical relief of the "Faglia centrale" post-dated the salinity crisis (post-Messinian reactivation?) but that the now downthrown side was probably located higher than the Cornaglia terrace, on the opposite side of the basin. The syn-rift character of the Messinian succession at Site 652 agrees well with this interpretation.

The Messinian Tyrrhenian basin was then limited to the western part of the present basin parallel to Sardinia. All that lies south-east of the base-of-slope results from very rapid, postMessinian extension.

A reinterpretation of all seismic lines available in the light of the new calibrations should be done.

\section{ACKNOWLEDGMENTS}

We thank the co-chief scientists and the shipboard party for accepting our sample request, and the persons who actually sampled the cores for us aboard the ship and at the core repository. Technical help was provided by Giancarlo Durando, Agostino Rizzi, Sergio Antico, and Franca Turrisi.

Financial support was provided by CNR, through Grant CT 86.675.

We thank Charlotte Schreiber, Cristina Broglia, Isabella Premoli Silva, Cesare Corselli, and Judy McKenzie for discussion and critical revision of the text. The very careful reviews provided by Ramil Wright and Jim Channell are gratefully acknowledged.

\section{REFERENCES}

Benson, R. H., 1973. Psychrosphaeric and continental ostracoda from ancient sediments in the floor of the Mediterranean. In Ryan, W.B.F., Hsü, K. J., et al., Init. Repts. DSDP, 13, Pt. 2: Washington (U.S. Govt. Printing Office), 1002-1008.

Bertolani Marchetti, D., and Cita, M. B., 1975. Palynological investigations on late Messinian sediments recorded at DSDP Site 132 (Tyrrhenian Basin) and their bearing on the deep basin desiccation model. Riv. It. Paleontol., 81:281-308.

Bossio, A., Esteban, M., Giannelli, L., et al., 1978. Some aspects of the Upper Miocene in Tuscany. Messinian Seminar no. 4, Field Trip Guideb., 1-88.

Chamley, H., and Robert, C., 1980. Sedimentation argileuse au Tertiaire supérieur dans le domain méditerranéan. Géol. Méditerran., 7:25-34.

Cita, M. B., 1973. Mediterranean Evaporite: paleontological arguments for a deep basin desiccation model. In Drooger, C. W. (Ed.) Messinian Events in the Mediterranean, Amsterdam (Elsevier), 206-228. 1975a. Foraminiferal biozonation of Pliocene deep-sea sediments from the Mediterranean. A revision. Riv. It. Paleontol., 81: 527-566.

1975b. The Miocene-Pliocene boundary. History and definition. In Saito, T., and Burckle, L. (Eds.) Late Neogene Epoch Boundaries, (Micropaleontology Press), 1:1-30.

1982. The Messinian Salinity Crisis in the Mediterranean: a review. In Hsü, K. J. (Ed.) Alpine-Mediterranean Geodynamics, Geodynamics Series, 7:114-140.

Cita, M. B., and McKenzie, J. A., 1986. The Terminal Miocene Event. In Hsü, K. J. (Ed.), Mesozoic and Cenozoic Oceans. Geodynamics Series, 15:123-140.

Cita, M. B., Vismara Schilling, A., and Bossio, A., 1980. Stratigraphy and Paleoenvironment of the Cuevas del Almanzora section (Vera Basin). A re-interpretation. Riv. It. Paleontol., 86:215-240.

Cita, M. B., Wright, R. C., Ryan, W.B.F., and Longinelli, A., 1978. Messinian Paleoenvironments. In Hsü, K. J., Montadert, L., et al. Init. Repts. DSDP, 42A: Washington (U.S. Govt. Printing Office), 1003-1035.
Fabbri, A., and Curzi, P., 1980. The Messinian of the Tyrrhenian Sea: seismic evidence and dynamic implications. G. Geol., 43:215-248.

Finetti, I., and Morelli, C., 1973. Geophysical Exploration of the Mediterranean Sea. Boll. Geof. Teor. Appl., 15:263-340.

Garrison, R. E., Schreiber, B. C., Bernoulli, D., Fabricius, F. H., Kidd, R. B., and Melières, F., 1978. Sedimentary Petrology and Structures of Messinian Sediments from the Mediterranean Sea. In Hsü, K. J. Montadert, L., et al. Init. Repts. DSDP, 42A: Washington (U.S. Govt. Printing Office), 571-612.

Gennesseaux, M., 1986. Une morphostructure distensive Plio-Quaternaire:la Tyrrhenienne centrale étudiée en submersible CYANA. SGFSGI Seance specialisée OCEANS, Abstr., 53.

Hajos, M., 1973. The Mediterranean Diatoms. In Ryan, W.B.F., Hsü, K. J., et al., Init. Repts. DSDP, 13, Pt. 2: Washington (U.S. Govt. Printing Office), 944-970.

Hsü, K. J., Cita, M. B., and Ryan, W.B.F., 1973. The Origin of the Mediterranean Evaporites. In Ryan, W.B.F., Hsü, K. J., et al., Init. Repts. DSDP, 13, Pt. 2: Washington (U.S. Govt. Printing Office), 1203-1231.

Hsü, K. J., Montadert, L., et al, 1978. Init. Repts. DSDP. 42A, Washington (U.S. Govt. Printing Office), 1-1249.

Hsü, K. J., Montadert, L., Bernoulli, D., Cita, M. B., Erickson, A., Garrison, R. E., Kidd, R. B., Melieres, F., Müller, C., and Wright, R. C., 1977. History of the Mediterranean salinity crisis. Nature, 267:399-402.

Kastens, K. A., Mascle, J., et al., 1987. Proc. ODP Init. Repts., 107: College Station, TX (Ocean Drilling Program).

Kastens, K. A., Mascle, J., Auroux, C., et al., 1988. ODP Leg 107 in the Tyrrhenian Sea: Insights into passive margin and backarc basin evolution. Geol. Soc. Am. Bull., 100:1140-1156.

Malinverno, A., Cafiero, M., Ryan, W.B.F., and Cita, M. B., 1981. Distribution of Messinian sediments and erosional surfaces beneath the Tyrrhenian Sea: geodynamic implications. Oceanol. Acta, 4: 489-496.

McKenzie, J. A., and Oberhansli, H., 1985. Paleoceanographic expression of the Messinian Salinity Crisis. In Hsü, K. J., and Weissert, H. (Eds.), South Atlantic Paleoceanography, Cambridge (Cambridge Univ. Press), 99-123.

Muller, D., and Hsü, K. J., 1987. Event stratigraphy and paleoceanography in the Fortuna Basin (SE Spain): A scenario for the Messinian salinity crisis. Paleoceanography.

Rehault, J. P., Moussat, E., and Fabbri, A., 1987. Structural Evolution of the Tyrrhenian Back-arc Basin. Mar. Geol., 74:123-150.

Ruggieri, G., 1967. The Miocene and later Evolution of the Mediterranean Sea. In Adans, C. G., and Ager, D. V. (Eds.) Aspects of Tethyan Biogeography, Syst. Assoc. Publ,, 7:283-290.

Ryan, W.B.F., Hsü, K. J., et al., 1973. Init. Repts. DSDP, 13, Pt. 2: Washington (U.S. Govt. Printing Office).

Schrader, H.-J., and Gersonde, R., 1978. The Late Messinian brackish to fresh-water environment, diatom floral evidence. In Hsü, K. J., Montadert, L., et al. Init. Repts. DSDP, 42A: Washington (U.S Govt. Printing Office), 761-776.

Selli, R., 1970. Cenni morfologici generali sul Mar Tirreno. G. Geol., 37:5-24.

Sissingh, W., 1976. Aspects of Late Cenozoic Evolution of the South Aegean Ostracode Fauna. Palaeogeogr., Palaeoclimatol. Palaeoecol., 20:131-145.

Wright, R. C., 1979. Benthic foraminiferal repopulation of the Mediterranean after the Messinian (late Miocene) salinity crisis. Palaeogeogr., Palaeoclimatol., Palaeoecol., 29:189-214.

Date of initial receipt: 10 February 1988

Date of acceptance: 27 January 1989

Ms 107B-161 


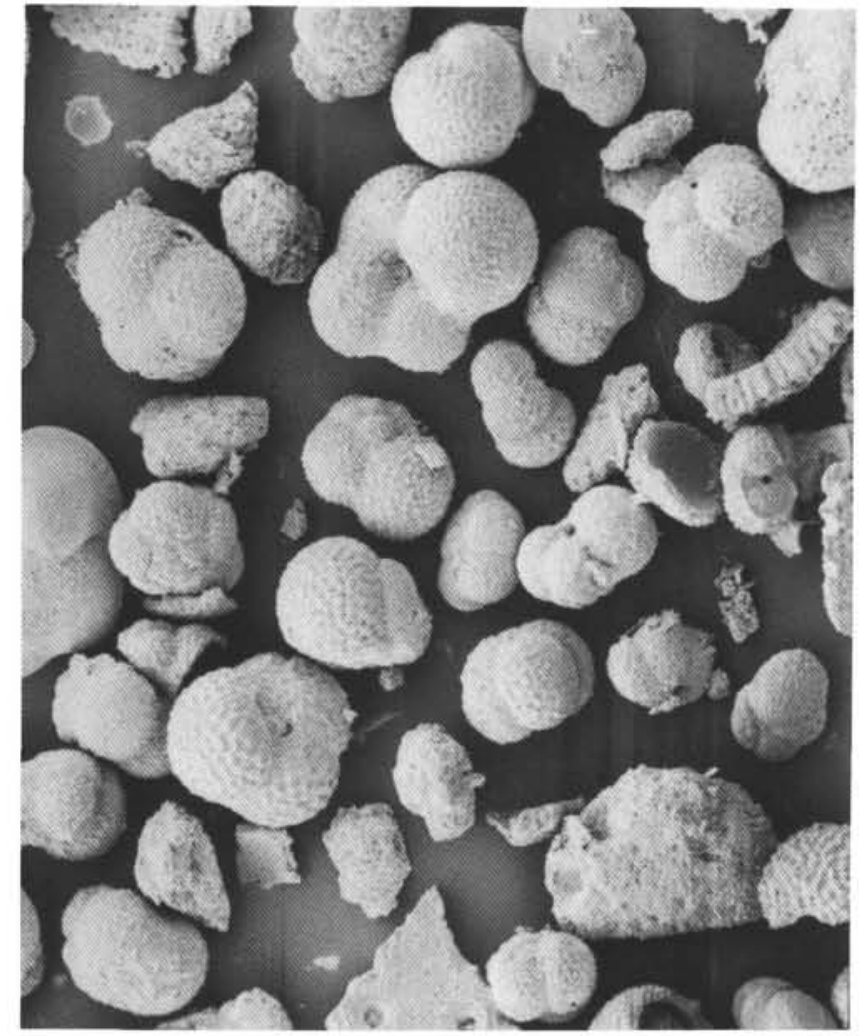

1

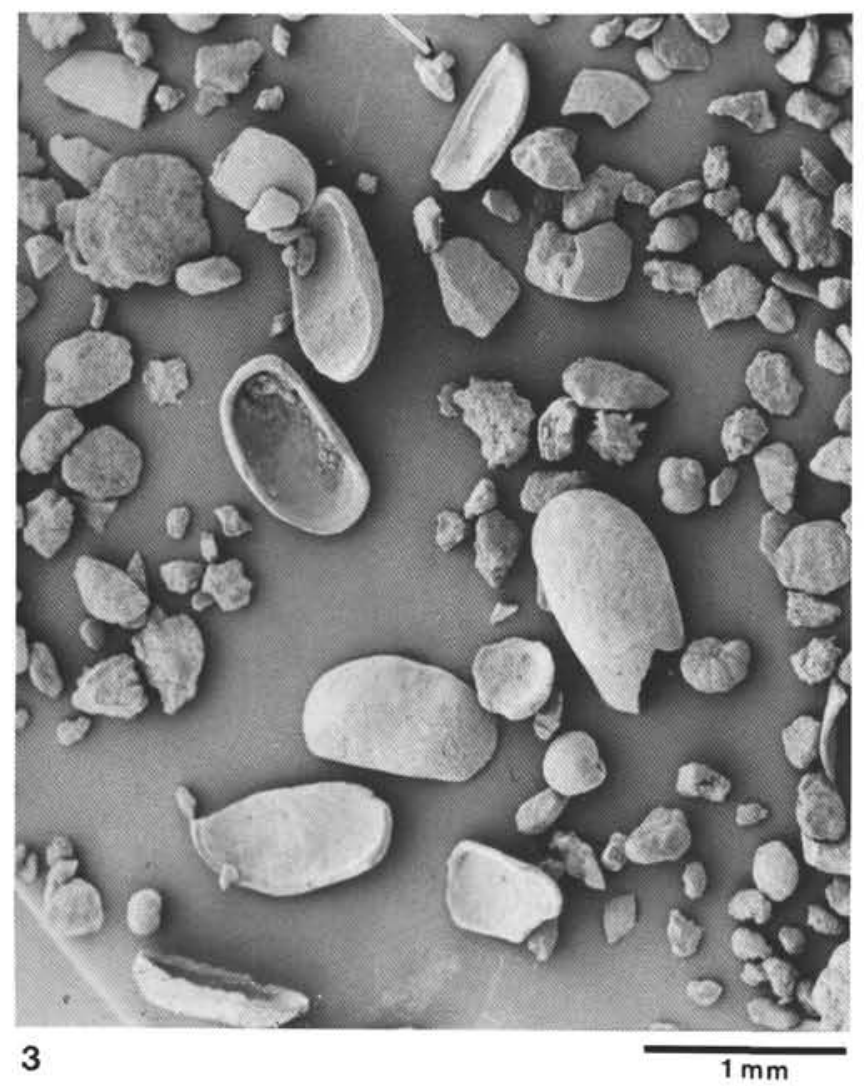

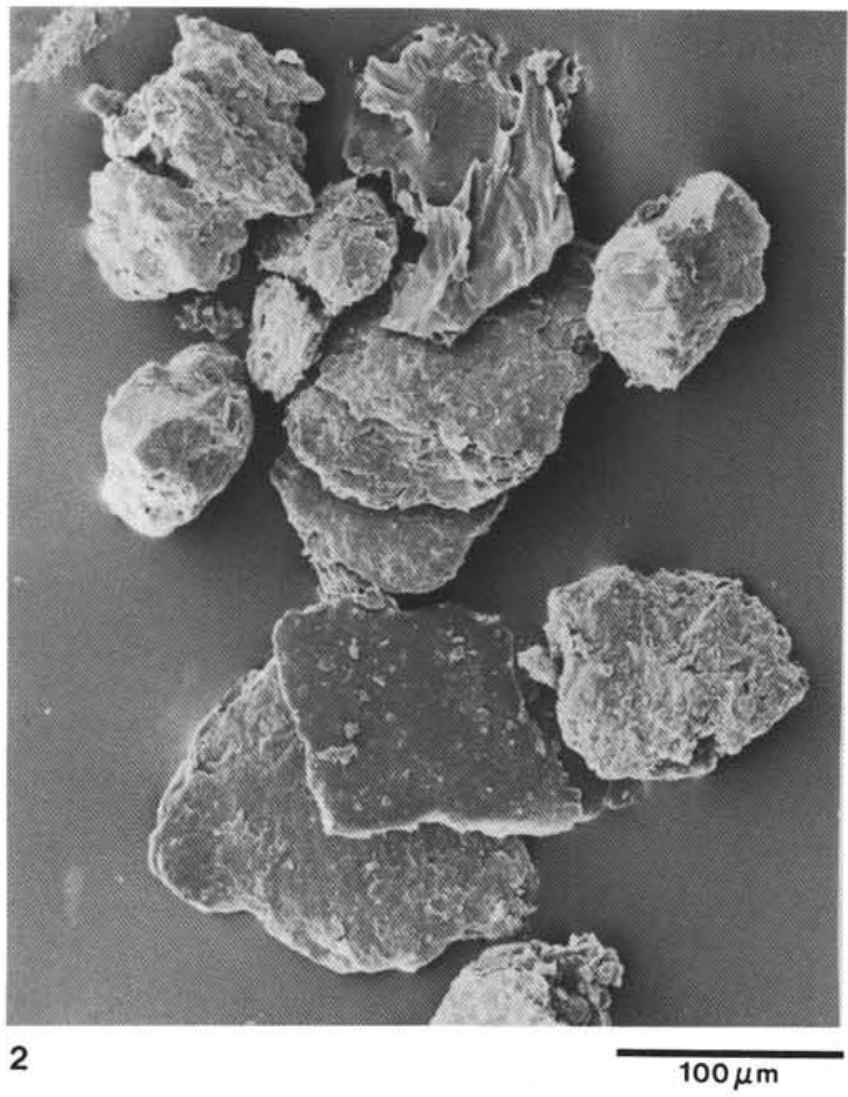

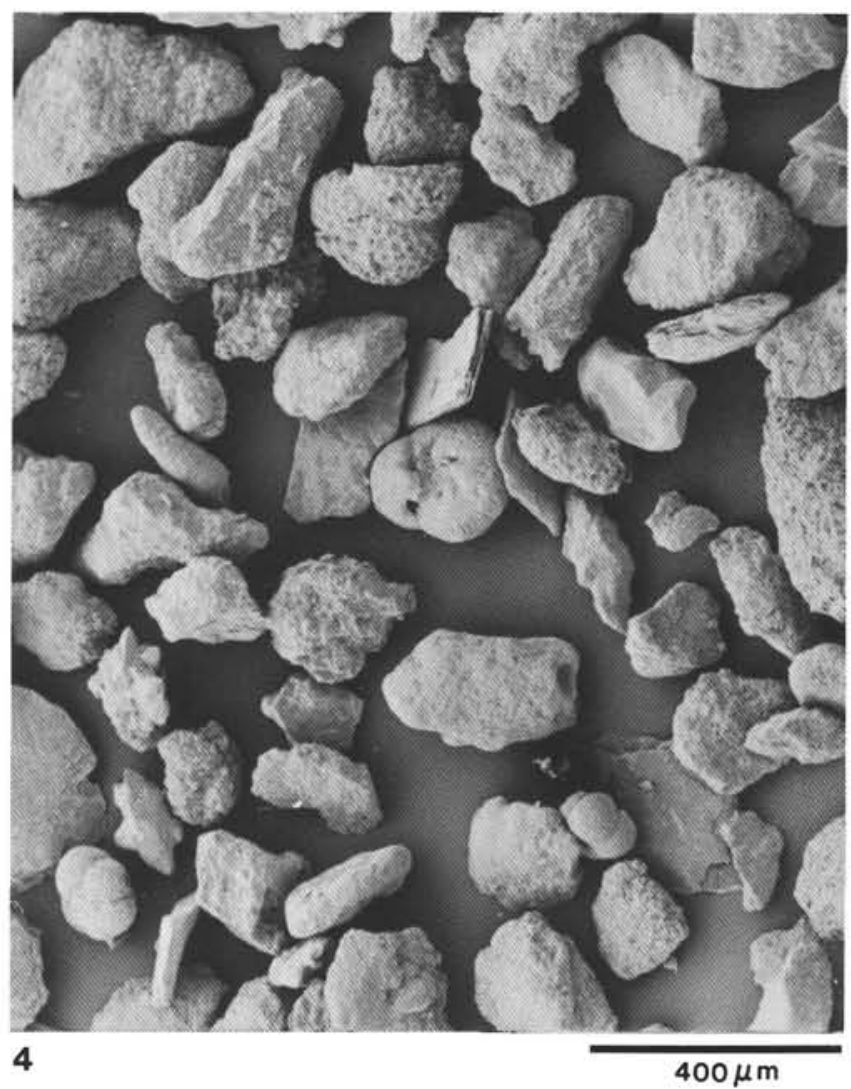

Plate 1. SEM micrographs of sand-size residues from ODP Site 654 . 1. Early Pliocene biogenic ooze $(654 \mathrm{~A}-26 \mathrm{R}-5,43-45 \mathrm{~cm})$. 2. Latest Messinian terrigenous sand (654A-28R-2, 84-86 cm). 3. Latest Messinian fossiliferous-gypsiferous sand with Cyprideis pannonica agrigentina (654A-28R4, 33-35 cm). 4. Latest Messinian gypsiferous sand with Ammonia beccarii tepida (654A-28R-4, 33-35 cm). 

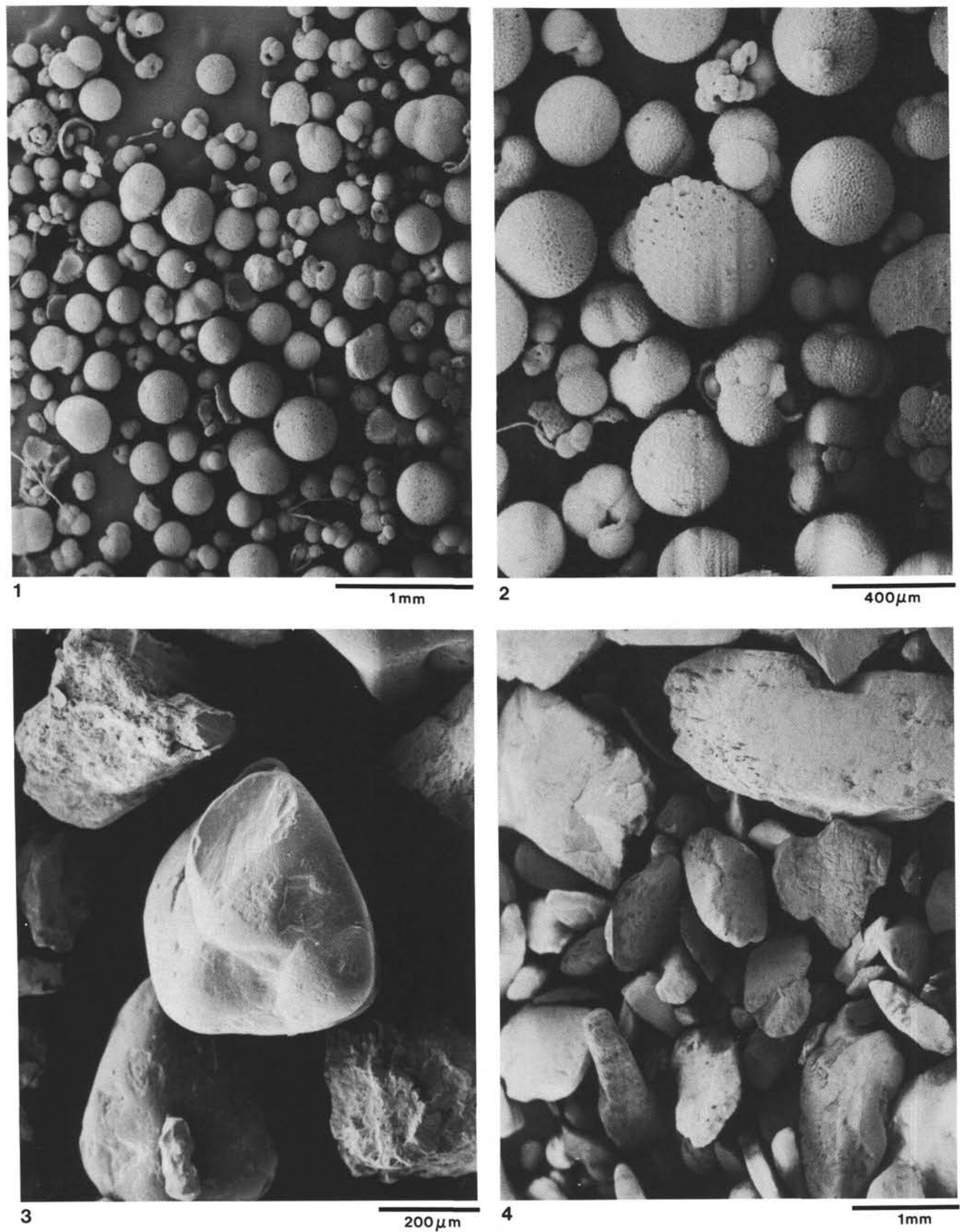

Plate 2. SEM micrographs of sand-size residues from ODP Site 653. 1 and 2. Early Pliocene biogenic ooze (653B-23X-4, 42-44 cm). 3. Frosted quartz grain in a late Messinian sand (653B-24X-1, 45-47 cm). 4. Gypsum-rich sand in the late Messinian (653B-28X-1, 51-53 cm). 

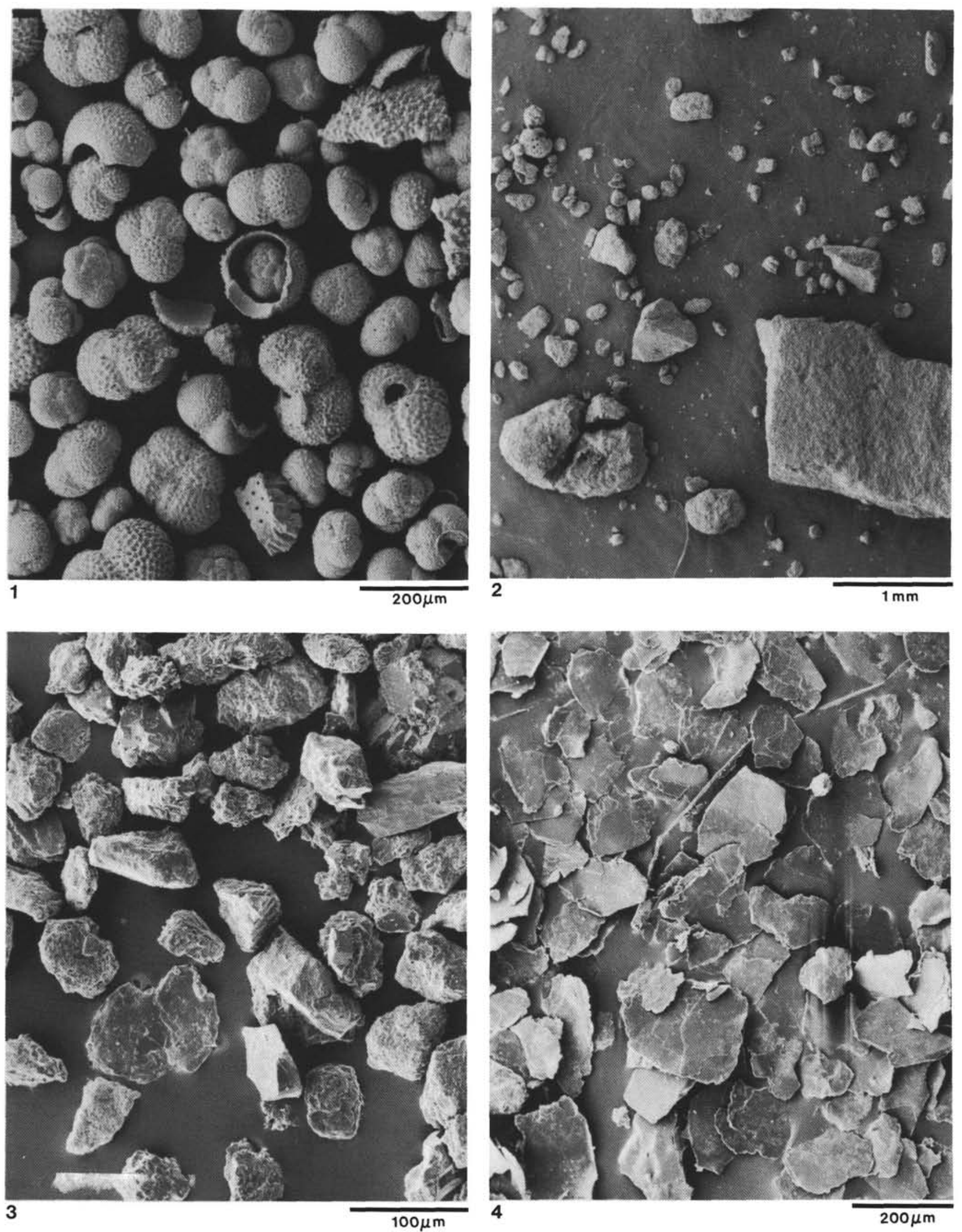

Plate 3. SEM micrographs of sand-size residues from ODP Site 652. 1. Early Pliocene biogenic ooze (652A-20R-5, 75-77 cm). 2. Transitional unit between the early Pliocene reddish oozes and the latest Messinian silts (652A-20R-6, 52-54 cm). 3. Late Messinian, Unit 4: siliciclastic carbonate sandy silt $(652 \mathrm{~A}-24 \mathrm{R}-1,54-55 \mathrm{~cm})$. 4. Late Messinian, Unit 4: micaceous silt (652A-24R-4, 50-52 cm). 

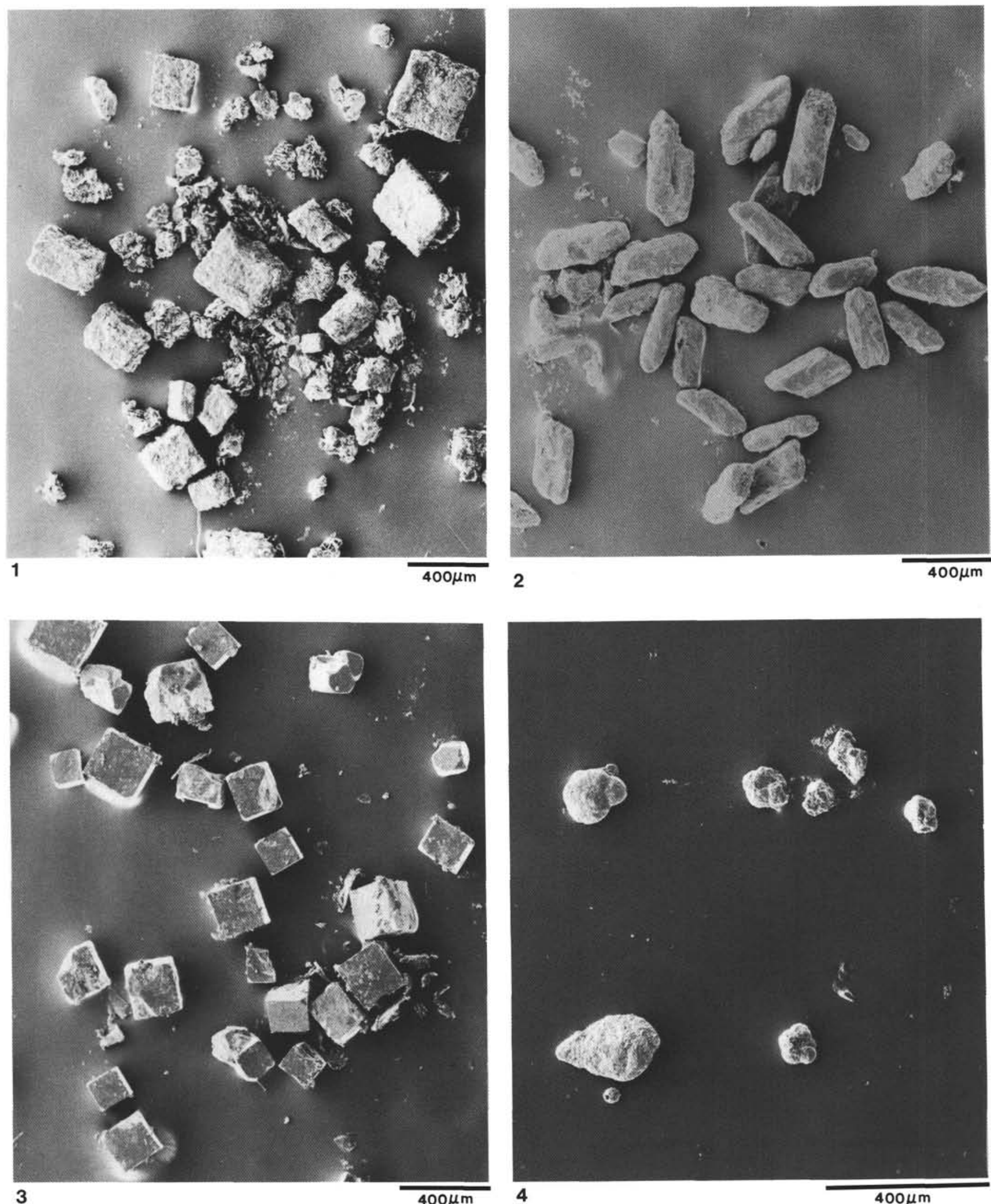

Plate 4. SEM micrographs of sand-size residues from ODP Site 652. 1. Messinian pre-conglomerate Unit 5: calcite and hematite compose the bulk of the residue $(652 \mathrm{~A}-58 \mathrm{R}-5,50-52 \mathrm{~cm})$. 2. Messinian pre-conglomerate Unit 5: gypsiferous silt (652A-60R-2, 49-51 cm). 3. Messinian pre-conglomerate Unit 5: pyrite crystals $(652 \mathrm{~A}-62 \mathrm{R}-2,48-50 \mathrm{~cm})$. 4. Messinian pre-conglomerate Unit 5: small-sized planktonic and benthic foraminifers $(652 \mathrm{~A}-63 \mathrm{R}-2,50-52 \mathrm{~cm})$. 